\title{
Understanding the perceived satisfaction and revisiting intentions of lodgers in a restricted service scenario: evidence from the hotel industry in quarantine
}

\author{
Kuo-Yan Wang ${ }^{1} \odot \cdot$ Mu-Lan $\mathrm{Ma}^{2}{ }^{2} \cdot$ Jing $\mathrm{Yu}^{1}$
}

Received: 4 September 2020 / Accepted: 5 May 2021 / Published online: 17 May 2021

(c) The Author(s), under exclusive licence to Springer-Verlag GmbH Germany, part of Springer Nature 2021

\begin{abstract}
The strict contactless management measures that have been implemented to control the spread of the COVID-19 pandemic have severely limited the ability of hotel staff to provide guest services in a quarantine scenario. This study examines the effect of lodgers' perceptions of the services provided in hotels under quarantine on their satisfaction and intentions to revisit. A self-administered questionnaire was distributed to 250 interviewees who had experienced lodging in quarantined hotel in Mainland China and Taiwan. A structural equation modeling technique was used to study the relationship between the model and the developed hypotheses. The study findings revealed that service perception dimensions are significantly related to customer satisfaction, and there is a positive correlation between customer satisfaction and their intentions to revisit. Moreover, the quality of hotel staff members' reliability and responsiveness was shown to be the most significant dimension of lodgers' perceptions of the services received in a quarantined hotel. Therefore, hoteliers who manage hotels that are under quarantine should carefully consider their service provisions in order to encourage lodgers to revisit.
\end{abstract}

Keywords Quarantine hotel · Restricted service · Customer satisfaction · Revisit intention

Mu-Lan Ma

1888@ms.nanya.edu.tw

1 School of Economics and Management, Guangdong University of Petrochemical Technology, Maoming 525000, China

2 Department of Hospitality Management, Nanya Institute of Technology, Taoyuan 320, Taiwan 


\section{Introduction}

The hotel industry has suffered an economic depression owing to the huge impact that the novel coronavirus disease (COVID-19) pandemic has had on the tourism industry. The crisis is unprecedented and moving quickly, yet remains deeply uncertain. COVID-19 has affected every sector across the globe, and the hotel industry is among the most affected. In the United States, as COVID-19 continues to devastate the hotel industry, the American Hotel \& Lodging Association (AHLA) released new data showing that $70 \%$ of hotel employees have been laid off or furloughed as 8 in 10 hotel rooms across the nation remain empty, which means that 2020 is projected to be the worst year on record for hotel occupancy (AHLA 2000; Sönmez et al. 2020). The hotel industry in the European Union countries has also been severely affected; for example, Italy experienced a decrease in revenue per available room from $-11.9 \%$ in February to $-85.5 \%$ in March; that in Greece declined from $-6.5 \%$ to $-52.4 \%$ within a month; and that in Spain decreased from $1.5 \%$ to $-38.7 \%$ (Statista 2020). China is no exception; during the peak travel season of the Chinese New Year and Spring Festival period, according to the performance data from January 23-26, 2020, the hotel occupancy was only $21.9 \%$, as compared to the average occupancy level of $55 \%$ in the past few years. The occupancy was $7 \%$ on February 2, 2020, and then stabilized at around 10\% (HVS 2020).

The impact of the COVID-19 pandemic on the tourism industry's revenues and supply chains has been substantial, yet unpredictable. Decisions to shut down hotels, restaurants, theme parks, and cinemas, in addition to the disruption to the overall travel ecosystem, have significantly affected worldwide tourism. To maintain operations and ensure profitability while increasing employment opportunities, hotels that meet certain hygienic standards have been designated as quarantine hotels to accommodate foreign travelers during their 14-day quarantine period as recommended by the World Health Organization (WHO). Despite the low entry threshold required to serve as a quarantine hotel, the practical differences in the complicated services required for general hotel operations, along with lodgers' perceived satisfaction with those services, have been affected. For example, quarantine hotels in the UK opened on February 17, 2021, but some guests staying in them have expressed concerns about their safety, the cost, and whether the quarantine hotel model works. For example, many tourists complained that the management of the quarantine hotel put them under severe personal restrictions (Davies 2021). In addition, tourists usually cannot choose a particular room or get an upgrade after they arrive, have only restricted amounts of outdoor exercise, and are subjected to obligatory Covid-19 tests during their stay. They receive deliveries of paper bags of food, hot or cold, three times a day; however, the room facilities sometimes do not work (Bailey 2021). Some guests do recount positive experiences at a quarantine hotel, including that all service requests can be responded to immediately, and they appreciate when hotel managers ask about their perceived service satisfaction (Yun 2021). Similar to ordinary hotels, it can be seen that the customer's satisfaction with the services provided in a quarantine hotel diverges from the perceptions of the hotel service provider. 
Further, although studies have attempted to determine the gaps between perceived service satisfaction and revisit intentions in the hospitality sector-studying, for example, the aviation, health, and tourist attraction industries (de Lima et al. 2019; Borghi et al. 2016; Molina et al. 2015; Ali et al. 2015) — the results have been inconclusive, because of the various definitions of the scope of service provision (Gilbert and Wong 2003; Basfrinci and Mitra 2015). However, given that service capacity is affected by external factors, customers' perceptions, satisfaction, and subsequent revisit intentions are also affected (Nunkoo et al. 2020; Shamsudin et al. 2019; Rather and Sharma 2017). Most hoteliers believe that meticulous service is a prerequisite in hospitality, but such meticulousness does not apply to every situation.

We aim to understand the perceived service satisfaction of lodgers during their stay in a quarantine hotel and whether such perceptions will affect their willingness to revisit. This type of information is rarely reported in the existing literature, in part because the lodgers and hotel service providers are not easy to approach face-toface due to social distancing requirements. In addition, some places have stipulated that non-local visitors who have ended their quarantine period must leave the city in which they were quarantined immediately. However, it seems logical that hotel visitors who are highly restricted by the external environment of the quarantine hotel are bound to be have a different level of satisfaction with their hotel stay than ordinary lodgers. Services offered in quarantine hotels are subject to greater restrictions owing to the COVID-19 epidemic. Therefore, the services offered, hotel guests' expectations and perceptions of these services, customer satisfaction, and subsequent revisit intentions are significantly affected. Hotels will resume normal operations following the end of the epidemic. The quarantine hotel industry is concerned about providing satisfactory services to quarantined lodgers and seeks expand its revisiting customer base. Maintaining the effectiveness of hotel operations is another concern.

Furthermore, although it is recognized that customer satisfaction and revisit intention are affected by service perception in hotel management, not many studies focus on quarantine hotels. Most studies focus on customer perspective in rating service quality perception and satisfaction before guest room booking and lodging experiences (Sönmez et al. 2020; Xu, 2020; Amfani-Joe et al. 2018) rather than their perceptions after lodging under service restriction resulting from external factors, that is, hygiene regulations and quarantine requirements. Therefore, lodger perceptions of service dimensions, customer satisfaction, and revisit intention require further studies.

Following an analysis of the literature on tourist satisfaction and the gap in the service content of the quarantine hotel, this study is theoretically justified for two reasons. In terms of the research on satisfaction, we observe that the existing literature has focused on verifying the extent to which this impacts guest satisfaction levels or their intention to revisit the hotel (El-Adly, 2019; Myo et al. 2019; Yarimoglu and Gunay 2020). However, this literature has not considered how such perceived satisfaction comes about, mainly in quarantine hotels; this is a context that is rarely studied and that tends to be different from the context of ordinary hotels. Thus, it is relevant to research and answer this question, including the variables that might impact the satisfaction that lodgers experience while staying in a quarantine hotel, 
such as received tangible and intangible services. Another novelty in this study is the consideration of whether this level of perceived satisfaction can be smoothly transformed into a willingness to revisit the hotel in the future when it has returned to being an ordinary hotel. We observe guests' responses in terms of their perceived satisfaction and their place of origin.

The results of this study seek to enable quarantine hoteliers to strengthen the direction of future operational improvement and attract customers after the pandemic is over by identifying which factors influence the satisfactions of visitors. Customer retention has become increasingly important, due to high competition among hotels and destinations (Al-Gharaibah 2020). Another practical justification emerges from the fact that without knowing what lodgers expect, the hospitality sector and local authorities might engage in actions and policies that are out of alignment with the objectives and expectations of visitors; this may generate dissatisfaction and even negative attention toward the destination itself (Basfrinci and Mitra 2015; de Lima et al. 2019). Thus, this study holds relevance for identifying how lodgers' perceived satisfactions and their revisiting intentions in quarantine hotels are shaped, and also puts forward an empirical model that seeks to identify possible operating solutions for the hotel's future.

The remainder of this paper is organized as follows. First, we review the literature on the relationship between customer satisfaction and revisit intentions, which (1) establishes the five foundations of service content, (2) notes the importance of a guest's place of origin in terms of service satisfaction, (3) conceptualizes the model and formulates hypotheses about the relationship between the hotel's perceived service dimensions and satisfaction and revisit intentions, and (4) considers the moderating role of a lodger's place of origin. Second, we describe the research method. Then, we present the main results of the tested model. Finally, we discuss the theoretical and managerial implications of the study, as well as its limitations and possible directions for future research.

\section{Literature review}

The literature identifies how satisfied customers are advantageous for the service providers; their satisfaction creates a ripple effect, which includes including loyalty to the service provider, engagement in positive word-of-mouth promotion, and paying premium prices (Ali et al. 2017, 2016; Dedeoglu and Demirer 2015; Amin et al. 2013). Therefore, customer satisfaction has garnered considerable attention from both academics and practitioners (Hultman et al. 2021; Assaker et al. 2020; Hu et al. 2009). In the tourism sector, these satisfactions interact with the type, variety, and quality of the services provided by a destination. Oliver (1980) defines satisfaction as a customer's emotional reaction to a specific product or service experience, and this reaction is developed based on the confirmation of a customer's perceptions and expectations of service performance. Cronin et al. (2000) deems that the indirect effects of service quality and value enhance their impact on behavioral intentions. Further, scholars believe that the satisfaction of customers may develop because of a single experience or because of a series of various experiences (Richard 2021; 
Ali and Raza 2019; Ali et al. 2016; Gonzalez et al. 2008). The relative weight of the affective antecedents on perceived value and satisfaction is significant (Gallarza et al. 2013), because these factors influence consumers' behaviors, including their repurchase intentions (Ali et al. 2016). Perceived satisfaction affects the willingness of visitors to revisit a destination according to their own place of origin (Bonera et al. 2017; Martín et al. 2020). Therefore, tourism service providers need to pay attention to the factors that form the satisfaction of visitors, so that they may meet them to the highest possible extent.

\subsection{Lodger satisfaction}

The focal products in the service sector are intangible and both service delivery and consumption occur simultaneously. Thus, consumers perceive greater risks when after receiving service (Wang et al. 2017). The intangibility of tourist services makes understanding how tourist's perceived satisfaction is formed even more complicated. Due to the complexity of the tourism activity, there are high levels of expectations regarding the experience that will be encountered which more significance than in other sectors such as banking or retailing, for example, in which the advantages and benefits are more tangible (Pereira et al. 2017).

The intangibility of tourist services can cause uncertainty in individual feelings. The more severe the negative service incident and the greater the attribution of responsibility to agencies within the destination, the more likely it is that an individual will develop hostile emotions toward the destination. The tourist may then decide to avoid the incident emotionally or to spread negative word-of-mouth about it. (Breitsohl and Garrod 2016). Understanding how this negative feedback is perceived by visitors and the factors that influence it can be a competitive advantage for tourist cities, which may focus their efforts on generating the most favorable image possible (Narangajavana et al. 2017). It is essential to highlight that image tends to be the source of tourist expectations and satisfaction (de Lima et al. 2019).

Recent scholars agree that satisfaction is a complex evaluative process involving multiple experiences; therefore, it should be measured using multi-item scales. Consequently, scholars have developed and adopted multi-item scales to measure customer satisfaction. For example, Bitner and Hubbert (1994) used four items to measure customers' overall satisfaction with the service provider. Similarly, Sureshchander et al. (2002) included five factors to measure customer satisfaction including the core service or service product, the human element of service delivery, the systematization of service delivery (the non-human element), the tangibles of service (the service scope), and the element of social responsibility. Westbrook and Oliver (1991) also used four emotion-laden items to assess customer satisfaction, which were adapted and tested in the context of the hospitality industry by Ali and Amin (2014).

In the hotel service industry, most studies on the relationship between customer's perceived value, satisfaction, and loyalty have considered customer perceived value as a unidimensional construct with emphasis on value for money. Perception of a service receiver can be categorized based on the following factors: quality (Wang 
et al. 2017; Jridi et al. 2014), esthetic (Choi and Kandampully 2019; Keng et al. 2007; Wu and Liang 2009; Mathwick et al. 2001), and cost performance (So et al. 2018; Kim et al. 2007; Sweeney and Soutar 2001). Customer perceived value has greater influence on service marketing because customers have become increasingly value-driven (El-Adly and Eid 2015). Customer's perceived value is a key antecedent of several behavioral outcomes such as patronage, re-patronage intention, customer satisfaction, and customer loyalty (Chen and Dubinsky 2003). Perceptions have a significant impact on customer's repurchase intentions (Choi and Kandampully 2019; El-Adly, 2019; Jalilvand et al. 2012; Ryu et al. 2008).

Although studies have confirmed that the perception of service value has a strong correlation with a firm's overall brand image, product/service quality, and customer's willingness to be a regular customer, it is not fully applicable to quarantine hotels because many services are restricted to prevent the potential risks of virus spread. However, a guest who stays in a hotel room quarantined for 14 days has a stronger perception of the service value than a short-term guest; in other words, lodgers naturally feel more strongly about the service. This study, therefore, examines the effect that lodger's service perceptions in terms of five main dimensions of service including dimensions with subjectivity and objectivity have on lodger satisfaction within a quarantine hotel.

\subsection{Foundation of perceptions of service quality model}

Armstrong and Kotler (2009) revealed that satisfaction consists of feelings of like or dislike that someone has for a product after he/she compares the product performance with his/her expectations. The subjective characteristics of the task of measuring consumers' perceived satisfaction (whether these are surpassed), as well as that of ascertaining the level of quality of service standards, represent a challenge for academia and for businesses and firms themselves. Hence, the model of the five gaps of service quality proposed by Parasuraman et al. (1985) is important. This model was developed through exploratory research with focus groups connected to the five different service types; this research identified common points that the clients deemed to be attributes of service quality.

The service quality model is the most widely used instrument to measure customer satisfaction in various industries and across different countries. This model is based on the notion of a specific set of quality determinants for each type of service. Five dimensions-tangibles, reliability, responsiveness, assurance, and empathy-were incorporated into a tool that can be used to measure a firm's service quality and assess customers' perceptions. The model remains the most widely applied framework and possibly the leading available model for measuring service quality (Etemad-Sajadi and Rizzuto 2013). Indeed, Woodall (2001) considers that service quality has effectively become the service quality model and vice versa. This model gives practitioners and researchers insight into service quality performance and provides a clear view of a company's competitiveness on the contemporary market (Ahmad et al. 2019). Management that focuses on customer satisfaction can improve loyalty and help to build a positive 
image of the company (Haque et al. 2014; Haur et al., 2017). In contrast, management that ignores customer satisfaction will risk the development of a negative public image related to the company and may reduce profits (Hafeez and Muhammad 2012). Maintaining customer satisfaction is important in terms of the quality of the company's products and services (Akhbar and Parvez 2009).

In tourism studies, most studies have focused on the difference between the customer's expectations of the service and his or her perceptions of service performance. The underlying idea is that the quality of a service is related to the gap between a customer's expectations and perceptions of the service (the customer perceived gap) (Li et al. 2017; Stefano et al. 2015; Lee 2013; Wei et al. 2011; Brown et al. 1993). Hospitality researchers have examined service quality gap for hotels in areas such as the appearance of the guest room, hotel staff performance, and the value of the cost performance (Stringam and Gerdes 2019; Fullinfaw and Sunil 2019; Al-Ababneh et al. 2018; Boon-Liat and Zabid 2013; Kinderis et al., 2011; Markovic and Raspor 2010). In addition to differences in business environment and function, research perspectives are also changing rapidly. For instance, Jasinskas et al. (2016) stated that using the service quality model to evaluate demanding lodger's loyalty and hotel's service quality. Later, Sangwan and Bhakar (2018) added customers' perception of a hotel chain brand image. Bravo et al. (2019) extended the study by Jasinskas et al. (2016) and found that hotel service expectations and demanding customer responses are linked by the service quality model. Stringham and Gerdes (2019) investigated a hotel official website load time performance compared against customer expectation benchmarks.

When a service provided is judged as insufficient, a customer commonly feels aggrieved and reacts emotionally, obviously the dissatisfaction will increase with the length of stay especially during a relatively long period (Hew et al. 2016). Despite Rajaguru and Hassanli (2018) and Mulyana and Prayetno (2018) were studied long stay lodger's service quality perception and satisfaction in budget and mid-scaled hotels, few studies have examined the intensity of such reactions determined by their lodging experience within the service context. Nonetheless, hotels assigned for quarantine use have all satisfied fundamental hygiene and facility requirements and ensured a short-term profitability. Strict contactless management owing to the COVID-19 pandemic has restricted the ability to provide general services. Consequently, hotels are concerned about maintaining reputation after the COVID-19 pandemic. These hotels must determine how to guarantee their occupancy rates as quarantine hotels while simultaneously ensuring that their future reputation is unaffected and possibly even expand their potential customer base. This empirical study addresses these issues as well. Thus, this study makes both theoretical and empirical observations to enhance hospitality measures by showing the differences in perception between quarantine hotels and their guests. The following discussion summarizes the current state of knowledge in five dimensions of the service quality model to examine how the model influences guest perceptions of service quality and satisfactory lodger outcomes in quarantine hotels. 


\subsubsection{Tangibles}

Parasuraman et al. (1988) used the term "tangible" in the service quality model as a dimension to evaluate service quality. Johnston (1995) divided tangibles into cleanness/tidiness and functionality in terms of serviceability and fitness for purpose. "Tangibles," also known as "physical qualities," commonly refer to tangible elements of the services, including the appearance of physical facilities, tools and equipment; personal communication materials; features used to provide the services; and the behavior of other customers in the service facility. Studies on services agree that tangibility is a multidimensional concept based on various outward appearances as experienced by different guests (Grönroos 1984; Parasuraman et al. 1985; Santos 2002; Hellén and Gummerus 2013; Jaakkola et al. 2015). All service performances involve physical components, such as consumables and durables, which can be seen, touched, and tasted, and which indicate a certain quality that a guest perceives. An organization's physical environment includes its overall layout, design, decoration, and esthetics (Lee and Jeong 2012). Bitner (1992) used the term 'services cape' to describe the man-made physical environment in which the delivery of service products takes place. This phenomenon has recently been found to be an important part of the consumer evaluation of satisfaction with services (Ruiz et al. 2012). In this sense, an adequate physical environment leads to more favorable customers' responses, affecting such things as their perception of comfort and the increased positive word-of-mouth (Ryu et al. 2008). Leong et al. (2018) showed that different values impact ones ability to visualize service. In practice, serviceability in quarantine hotels differs from that in ordinary hotels, as many service processes and facilities may be omitted or closed; for example, the porters, concierge, bars, restaurants, conference and meeting rooms, sports facilities, beauty services, and souvenir shops have little to no accessibility in a quarantine hotel. Consistent with various studies, the tangibility of customer perception measures the extent of service qualification.

\subsubsection{Reliability}

Amid intense competition in the hotel industry, service reliability is an important facet of interest to researchers. In an empirical study, Wahid et al. (2017) showed that reliability has a significant direct effect on customer satisfaction. As an integral part of internal customer relationships, reliability showed that employee rewards are crucial for customer service (Bawa 2017). Baek et al. (2019) also concluded that positive and negative employee interactions in the lifestyle hotel segment were more important in the overall reviews than in the traditional hotel segment, and thus affect the reliability of the service process. Under the benign interaction, the service staff is pleased to provide better service and deepen the customer's good impression. Simultaneously, tourism crowdsourcing platforms accumulate and use large volumes of feedback data on tourism-related services to provide personalized recommendations with high impact on future tourist behavior (Xiang et al. 2018). These recommendation engines build individual tourist profiles and suggest hotels, restaurants, attractions, or routes based on the shared ratings, reviews, photos, videos, or likes (Veloso et al. 2020). Often, a lodger is unable to choose his or her favorite 
place as a quarantine hotel, but they can observe whether the reliability satisfies the needs during those 14 days, then form a basic impression of the lodged hotel based on their own feelings and others' opinion.

\subsubsection{Responsiveness}

Studies have recognized that customers' perception is essential for developing the hotel's responsiveness. Organizations must be adept at addressing problems to retain customer relationship. Guix et al. (2018) indicated that hoteliers increase their development sustainability by responding to customers' concerns. Studies have shown that effective responsiveness, for example, responding to guest's queries promptly, politely, and professionally (Jazira et al. 2011), increases development sustainability. Internal and external information sharing are important antecedents of customer responsiveness and satisfaction, although cleanliness, comfort of rooms, quality of food, and friendliness are significant as well (Tiedemann et al. 2009). Hence, a hotel's reputation depends on the transparency of information (Žabkar and Arslanagić-Kalajdžić 2014). Compared with an ordinary hotel, lodgers at a quarantine hotel are required to abide by the quarantine measures, such as checking temperature, regular nucleic acid testing, meal delivery time, and other room service demands. Unclear stipulations not only cause communication errors, but also severely damage the quarantine hotel's image of the services.

\subsubsection{Assurance}

Assurance has a constructive relationship with customer satisfaction (Lee et al. 2018; Liat et al. 2014). The term "assurance" refers to knowledge and courtesy of employees and their ability to convey trust and confidence that is also a critical factor of significant positive effect on customer satisfaction (Shah et al. 2018). As a basic dimension to measure the level of service quality, service assurance is sufficient to affect customer satisfaction (Mohamad et al. 2017). Assurance is demonstrated through hotel staff skills and competence, courteousness, and ability to inspire trust and confidence in the guests being serviced (Fredrick 2019; Shahin et al. 2010; Shahin et al. 2006; Parasuraman et al. 1985). Studies on hospitality found that service assurance for hotels significantly influences customer perception ( $\mathrm{Su}$ et al. 2020; Aguiar-Quintana et al. 2016; Lam and Zhang 1999). Additionally, travelers who are involved in health care also demand more protection when they receive services (Manna et al. 2020; Collins et al. 2019; Pan and Moreira 2018; Drinkert and Singh 2017). For many travelers, the quarantine period is an unforgettable experience, but such experience may be ambiguous. As far as the customers of the quarantine hotel are concerned, due to confined at a limited space and external restrictions on their movements, lodgers must pay more attention to the provision of services, in other words, they will pay more attention to punctuality and service delivery. Therefore, 
assurance is also one of the key points of observation to measure quarantine hotel's service quality in this study.

\subsubsection{Empathy}

Several studies on hotel service have focused on empathy by considering cognitive and emotional attributes and how they impact the emotional service experiences and behavioral intentions among business and leisure hotel guests. Empathetic services based on a "purpose of visit" improve the guest's overall emotional response (Umasuthan et al., 2017). Culture is a determinant of expressing empathy; for example, people from collectivist cultures may be more tolerant and satisfied with service encounters (Donthu and Yoo 1998; Malhotra et al., 2005; Zhang et al., 2008). However, service providers should anticipate customers' deference by establishing and communicating acceptable behaviors, managing physical distance with customers, and monitoring customers' nonverbal behavior and facial expressions to detect their true feelings (Wongkitrungrueng et al. 2019). This study determines whether the empathy displayed is reduced if the relationship between a hotelier and a tourist is constrained by the external environment.

The above-mentioned approach was the analysis method taken by Han et al. (2011) and Yang and Lau (2015) in analyzing the relationship between services that a customer received and his/her perceived satisfaction. Correspondingly, we seek to identify whether the service quality that a quarantined hotel lodger received matches the perceptions of tourism service providers as regards those same expectations.

To respond to this question, we set out Hypothesis 1-5 that assumes there are positive correlations between the services that a quarantined hotel guest received and his/ her perceived satisfaction. Our assumptions are theoretically based on Parasuraman et al.'s (1985) five-dimension quality model, which indicates that the model is suitable for any service, including hospitality sector services. Thus, the five proposed hypotheses are:

H1 Tangibles have a positive effect on lodger perceived satisfaction toward quarantine hotel services.

H2 Reliability has a positive effect on lodger perceived satisfaction toward quarantine hotel services.

H3 Responsiveness has a positive effect on lodger perceived satisfaction toward quarantine hotel services.

H4 Assurance has a positive effect on lodger perceived satisfaction toward quarantine hotel services.

H5 Empathy has a positive effect on lodger perceived satisfaction toward quarantine hotel services. 


\subsection{Lodger revisit intention}

Customer revisit intention has been extensively studied in the service industry. It emphasizes building and maintaining long-term and positive interaction with customers for sustainable development of the business. For example, a hotel's external and internal ambience has been found to have a significant correlation with customers' satisfaction with a hotel and its departments, as well as with customer preferences and revisit intentions (Kandampully and Suhartanto 2000; Padma and Ahn 2020; Ying et al. 2020). Hoteliers usually are committed to enhancing guest revisit retention, because the cost of soliciting new customers is seven times higher than that of retaining old ones (Richard and Larry 1996; Reichet al. 2006), and because enhancing customer retention will lead to increased profits. In order to enhance the retention of customers, it is essential for hotel managers to understand the relationship between customers' satisfaction and customer retention.

In addition to customer perceptions of a service experience, studies have focused on "destination branding" in tourism marketing and demonstrated a positive relationship between a place's brand image and its reputation (San Martín Gutiérrez et al. 2018; Foroudi et al. 2016; Kaplan et al. 2010; Um et al. 2006). Researchers have concurred that cognitive and affective associations with the destination image influence customer revisit intentions (e.g., Ahn and Kwon 2020; Hwang and Han 2016; Brown et al. 2016). Additionally, satisfaction and visit frequency are related. Woo (2019) showed the impact of visit frequency on the relationship between service quality and satisfaction. The perceived experiential quality directly affects the perceived image (Aydin and Ozer 2005). Padma and Ahn (2020) found that the quality of hotel rooms and interactions with employees have been determined as major drivers of customers' word-of-mouth and revisit intentions. Jin et al. (2013) showed that experiential quality significantly affects the perceived image. Therefore, the visitors' perception of experiential quality helps to create the perceived image in terms of the tourism context.

Although much of the existing work has addressed issues of the relationships between customer satisfaction and revisit intentions, from a quarantine hotel user's perspective, little attention has been given to a model that operationalizes the latent factor of "customer retention" by means of the perceived satisfaction of customers and their "intent to switch." Han et al. (2011) examined the intricate relationships among a hotel's core services and service encounter performances, customer satisfaction, and overcoming barriers in the formation of satisfaction and switching intention. Their study revealed that both core services and service encounter performances significantly affected customer satisfaction, and perceived satisfaction completely mediated the effects of service performances on switching intention; however, this study only investigated upper-midscale hotels. In the other hand, Yang and Lau (2015) surveyed 285 guests who stayed in five-star hotels in Macau, China, and they considered the generation (age) of the guests as the moderating role. They found that a comparison of the "Generation X" group (persons born from 1965 to 1980) versus "Millennials" (persons born between 1981 and 1994) revealed that satisfaction did not induce revisit intention. Moreover, the focus on hotel service satisfaction was also different between the two generations of the Generation $\mathrm{X}$ and 
the Millennials, but this study did not discuss the differences in hotel operational patterns in terms of service differentiation and the willingness of customers to make return visits.

Accordingly, in this study, we investigated that how the latent factor of customer retention could be operationalized in terms of perceived satisfaction of the customer to the hotel, and their intent to revisit the quarantine hotel they have lodged. Therefore, based on the service quality model, this study finds that a greater awareness of the quarantine hotel improves lodgers' cognitive and affective associations with the place. Consequently, the following hypothesis is proposed:

H6 Lodger perceived satisfaction has a positive effect on lodger revisit intention toward quarantine hotel services.

\subsection{Lodger's place of origin}

Tourists' place of origin plays a significant role in customer satisfaction and revisit intentions (Pizam and Sussmann 1995; Steenkamp and Geyskens 2012; Cheng et al. 2019a, b). Various sociodemographic features and behavioral characteristics of tourists' places of origin resulted in differences in the perceptions of services that they formed and their image of the touristic quality of the destination; relevant factors included leisure activities, catering, and lodging. Ying et al. (2020) discovered that Chinese tourists belonging to a high-power distance culture were accustomed to following social norms and expecting personalized service in accordance with their enhanced social status. However, North American guests mainly tended to highlight the lifestyle-related attributes and to ask for standardized service. Prayag and Lee (2019) evaluated the mediating effects of service interactions with hotel employees on the relationship between tourist motivation and place attachment and found that the relationship differed according to tourists' places of origin and the hotels' star rating. Huang and Crotts (2019) assumed that the cultural values that included direct measures of an individual's culturally derived values showed that individual norms and values were strongly related to their evaluative judgments.

Similarly, differences in customer perceived satisfaction among guests who belong to the same cultural circle have been discussed in previous studies. For example, in the context of the cross-strait service sector, Mainland China and Taiwan travelers perceive certain service attributes (safety, reception attitude, cleanliness) differently (Lu and Ling 2008). Even though the general service structure was the same for both Taiwan and Mainland China visitors, to ensure that service quality attributes meet the needs and expectations of both market segmentations, practitioners should develop targeted marketing strategies for each service element (Cheng et al. 2019a, b). Perception differences will affect service satisfaction. Pan (2014) investigated the Mainland Chinese tourists' attitude toward sightseeing spots in Taiwan, and they found that the cleanliness of the streets, of which locals in Taiwan feel proud, were ranked last in the survey; instead, the availability and quality of snacks were the most important. Another difference is reflected in the deficiency of 
emotional engagement. Despite tourism service providers providing adequate facilities, the lack of emotional interaction with guests can lead to customer dissatisfaction and make them less likely to revisit the destination (Wu and Chang 2019).

A literature review identified that native and non-native lodgers differ in perceived service satisfaction and revisit intention. Native lodgers easily compare the differences in service satisfaction between the hotel and one's home because of the stipulated period of home isolation following the 14-day hotel quarantine. Therefore, whether the individual is home-returned tourist or non-local traveler plays a moderating role in this study on quarantine hotel service. To test the moderating role of the place of origin on the relationship between perceived service satisfaction and revisit intention, the following hypothesis is proposed:

H7 Lodgers from native place versus non-native lodgers moderate the relationship between perception and satisfaction.

\subsection{Proposed model}

Based upon the hypotheses underpinning this study, this study constructed the model featured in Fig. 1 based on that proposed by Cheng and Rashid (2013) to investigate the relationships between the perceived satisfaction and the revisit intention of quarantine hotel tourists. Further, it includes the five dimensions of the service quality model that were proposed by Parasuraman et al. (1985).

The design of this model enables the portrayal of how lodger revisit intention forms. The first route establishes that the relationship between the five elements of service quality and a lodger's perceived satisfaction constitutes the primary relationship, in keeping with how satisfaction is formed in the minds of individuals and how

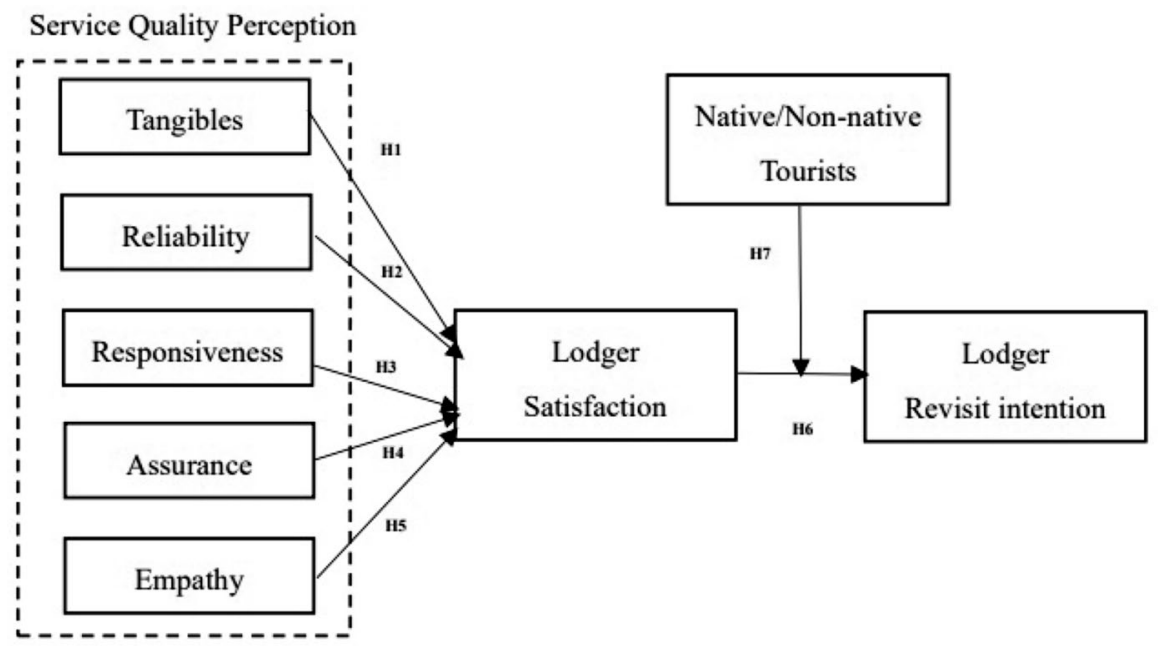

Fig. 1 Conceptual model 
it may lead to the desire to revisit in the future (Shams et al. 2020; Shamsudin et al. 2019; Ban et al. 2019; Cheng and Rashid 2013).

Based on this connection, it becomes necessary to verify which aspects shape and influence the quarantine hotel lodger's satisfaction, as well as whether such satisfaction can be successfully converted into revisit willingness. Therefore, the second route constructs the relationship between lodger perceived satisfaction and revisit intention that was proposed by Cheng and Rashid (2013). As for the lodger's place of origin (whether he/she is native or non-native) is used as a moderating variable, and used to observe whether the satisfaction mentioned above will affect the willingness to revisit. The testing of these relationships is necessary for the evaluation of comparative hypotheses.

In summary, the first part of this section sought to verify how quarantine hotel lodgers' sense of satisfaction forms, as set out in the model proposed in Fig. 1. This second part, based upon the verified results, observed the relationship between perceived satisfaction and revisit intentions. We tested the hypotheses, adapting the questionnaire for application to lodgers and measuring their opinions regarding hotel service satisfaction and revisit intentions in accordance with their place of origin.

\section{Methodology}

This study is based on the observations of quarantine hotels during the ongoing COVID-19 pandemic. In order to achieve the objectives of this study-to identify the perceived satisfaction for lodgers under restricted services in a quarantine hotel and to identify whether the perceived satisfaction of lodgers can be successfully converted to revisit intentions-we opted for a descriptive and quantitative research methodology, with a cross-sectional sample of the primary data.

The research correspondingly drew upon lodgers living in the quarantine hotel. We applied the non-probabilistic accessibility technique to build our sample; we incorporate scales already tested and validated by the scientific literature and use a total of 37 questions, the first serving as a control, as explained above. The questionnaire has the following structure: items 1-22 measure constructs for received service content quality (Stefano et al. 2015; Akbaba 2006), four items related to customer perceived satisfaction (Cheng and Rashid 2013), and five items related to customer revisit intentions (Cheng and Rashid 2013; González-Romá et al. 2002) (See Online Appendix). Items 32-37 deal with the demographics of the respondents (gender, age, travel purpose, place of origin, the estimate period of residence and occupation (Table 6). As already explained, the text of the questions was modified so as to be closer to the actual perception of the isolated hotel. In the end, six demographic questions characterized the respondents in terms of gender, age, travel purpose, place of origin, the estimate period of residence, and occupation.

Six hotels designated for quarantine use in Mainland China and Taiwan were studied in mid-April 2020 to identify and explore issues associated with hotel hospitality. The general managers or those in charge were contacted. All except two hotels agreed to participate on the condition of anonymity. The random study sample 
Table 1 The characteristics of the surveyed quarantine hotels

\begin{tabular}{llllll}
\hline Hotel & Location & Area & Rooms & Type & Respondents \\
\hline A & Taiwan & suburbs & 180 & Business & 60 \\
B & Mainland China & suburbs & 500 & Business & 80 \\
C & Mainland China & downtown & 160 & Leisure & 50 \\
D & Taiwan & suburbs & 250 & Leisure & 60 \\
\hline
\end{tabular}

included quarantine hotels of varying size, purpose (business or leisure), and location. Table 1 describes the participating four hotels.

A multi-item questionnaire was constructed to study the key features of the services provided in the quarantine hotel. This empirical survey evaluates the five dimensions of a service from the viewpoint of customer perceptions using a 5-point Likert scale (from 1=Extremely Disagree to 5=Extremely Agree). The questionnaire emphasizes a lodger's satisfaction during the 14-day stay at the quarantine hotels.

To validate the content of the questionnaire, a pre-test was performed with the questionnaire. The pre-test of the tourists' questionnaire was sent to ten respondents who were lodging at the surveyed quarantine hotel to verify possible misunderstandings that might arise. We observed that there was an understanding of all of the statements, validating the content of the questionnaire. We subsequently made the questionnaires available via instant messaging apps, such as WeChat and Line, with each questionnaire sent to distinct groups of possible respondents to avoid any potential bias in the responses should the same individual answer more than once. The questionnaires were available to respondents from May 1 to 30, 2020. Analyzing by SPSS 23.0, all item scales used in this study and the descriptive analysis result are presented in Appendix.

Following this data collection process, we obtained 310 responses to the questionnaire, with 250 valid submissions with approximately $80.6 \%$ response rate (Table 2). The respondents included 50.8\% (127) females and 49.2\% (123) males (Table 2); 66\% (165) were 39 years or younger and 32.4\% (81) aged 40-59 years. More than half the respondents (133) were traveling for long-term jobs or to attend meetings (53.2\%), 39.2\% (98) were traveling for family visits or personal reasons, and only $6.4 \%$ (16) were tourists. Furthermore, $66.4 \%$ (166) of respondents were native, while $33.6 \%$ (84) non-native. Of the respondents, $70.0 \%$ (175) indicated an intended stay of over 6 months, while $18.8 \%$ (47) intended to stay for 4-6 months; as visitors to most countries must be under quarantine for 14 days, there are fewer stays spanning less than 30 days. Regarding the respondents' occupations, $40.8 \%$ (102) were returning students and $52.4 \%$ (131) were private sector employees.

To analyze the data and test our hypotheses, we applied a multivariate analysis through structural equation modeling by AMOS 22.0. We opted for this technique, given its robustness in evaluating concomitant associations among endogenous and exogenous variables. We obtained the validity of the structural model using 
Table 2 Demographics of respondents $(n=250)$

\begin{tabular}{|c|c|c|}
\hline Variables & Sample size & Percentage $(\%)$ \\
\hline \multicolumn{3}{|l|}{ Gender } \\
\hline Male & 127 & 50.8 \\
\hline Female & 123 & 49.2 \\
\hline \multicolumn{3}{|l|}{ Age } \\
\hline $20-29$ & 72 & 28.8 \\
\hline $30-39$ & 93 & 37.2 \\
\hline $40-49$ & 58 & 23.2 \\
\hline $50-59$ & 23 & 9.2 \\
\hline 60 and above & 4 & 1.6 \\
\hline \multicolumn{3}{|l|}{ The purpose of travel } \\
\hline Visiting friends and relatives & 24 & 9.6 \\
\hline Business & 126 & 50.4 \\
\hline Personal (family, medical, wedding or others) & 74 & 29.6 \\
\hline Sightseeing & 16 & 6.4 \\
\hline Meetings, conventions, seminars & 7 & 2.8 \\
\hline Others & 3 & 1.2 \\
\hline \multicolumn{3}{|l|}{ Place of origin } \\
\hline Native tourist & 166 & 66.4 \\
\hline Non-native tourist & 84 & 33.6 \\
\hline \multicolumn{3}{|l|}{ Estimated period of residence } \\
\hline Less than 1 month & 12 & 4.8 \\
\hline 1-3 months & 16 & 6.4 \\
\hline 4-6 months & 47 & 18.8 \\
\hline Above 6 months & 175 & 70.0 \\
\hline \multicolumn{3}{|l|}{ Occupation } \\
\hline Returned student & 102 & 40.8 \\
\hline Private sector & 131 & 52.4 \\
\hline Public sector & 6 & 2.4 \\
\hline Freelance & 9 & 3.6 \\
\hline Unemployed/Retired & 2 & 0.8 \\
\hline
\end{tabular}

confirmatory factor analysis, verifying both the convergent validity and the discriminant validity. We subsequently tested our hypotheses.

In addition to testing the hypotheses, there was also the need to ascertain any differences in the path coefficients of each variable, according to the indications of Hult et al. (2018); this was necessary, because, as Hair et al. (2017) mentioned, it is not possible to affirm that parallel path coefficients in the same model are distinct based only on their significance and their indicators. This method was chosen because it is a structural equation modeling technique that can test models with unobserved variables 
or constructs (Byrne 2016), as well as solve various forms of construct operability (Henseler 2018).

\section{Results}

\subsection{Measurement model assessment}

To evaluate the model constructs and validate the appropriateness of the data collected, we carried out a confirmatory factor analysis to ascertain the convergent and discriminant validity. For the study of the confirmatory factor matrix, we calculated the factorial weightings for the research assertions about their constructs.

The convergent validity refers to the extent to which the construct indicators measure the construct, thus indicating the extent to which these variables correlate with each other (Hult et al. 2018). Discriminant validity refers to the capacity of a construct to be genuinely distinctive (Hult et al. 2018). In this study, using the factorial matrix, we observe how the factorial weightings identify various factors. No cross weightings were reported among the constructs, confirming the discriminant validity. As Table 3 (the factor loading results) shows, there is no obvious variable across the two latent variable factors in the model. The originally constructed explicit variables all fall within the expected latent variable factor framework, and the factor loadings are all greater than 0.5 , indicating that the model has good discriminative validity (Arifin and Yusoff 2016). Further, Table 4 reveals that the cumulative variance explanation rate after rotation was $84.555 \%$, meaning that the information embedded in the research item can be extracted effectively (Samuels 2017; Guadagnoli and Velicer 1988).

To complement the verification of this study's convergent validity, we also calculated the validity of the average variance extracted (AVE) before concluding that all of the latent variables attained the set criteria. Composite reliability (CR), which also represents an indicator of convergent validity, ensures the evaluation of the magnitude by which the items in an instrument correlate with each other. In the present study, a confirmatory factor analysis (CFA) analysis was performed for a total of 7 factors and 31 analysis items. It can be seen from Table 5 that the KMO value is 0.933 , which means that the data is valid; also, the AVE values corresponding to a total of 7 factors are all greater than 0.5 , and the CR values are all greater than 0.7 , which means that the data in this analysis has good convergence validity (Hair et al. 2017 and Khan et al. 2019).

Finally, to fulfill the discriminant validity, we compared the square roots of the AVE for each construct with the results returned by their respective correlations, as proposed by Fornell and Larcker (1981). The AVE square root index for each latent variable was higher than that of the other construct, indicating their respective mutual independence. Table 5 illustrates the correlations and quality criteria. 
Table 3 Factor loadings

\begin{tabular}{|c|c|c|c|c|c|c|c|c|}
\hline Variables & TA & $\mathrm{RB}$ & $\mathrm{RP}$ & AS & EP & SA & RV & $\begin{array}{l}\text { Common fac- } \\
\text { tor variance }\end{array}$ \\
\hline TA1 & 0.926 & & & & & & & 0.966 \\
\hline TA2 & 0.893 & & & & & & & 0.872 \\
\hline TA3 & 0.912 & & & & & & & 0.895 \\
\hline TA4 & 0.864 & & & & & & & 0.892 \\
\hline RB1 & & 0.805 & & & & & & 0.914 \\
\hline RB2 & & 0.768 & & & & & & 0.788 \\
\hline RB3 & & 0.696 & & & & & & 0.827 \\
\hline RB4 & & 0.790 & & & & & & 0.789 \\
\hline RB5 & & 0.658 & & & & & & 0.633 \\
\hline RP1 & & & 0.824 & & & & & 0.823 \\
\hline RP2 & & & 0.868 & & & & & 0.934 \\
\hline RP3 & & & 0.839 & & & & & 0.847 \\
\hline RP4 & & & 0.848 & & & & & 0.828 \\
\hline AS1 & & & & 0.880 & & & & 0.847 \\
\hline AS2 & & & & 0.899 & & & & 0.876 \\
\hline AS3 & & & & 0.929 & & & & 0.948 \\
\hline AS4 & & & & 0.777 & & & & 0.815 \\
\hline EP1 & & & & & 0.802 & & & 0.936 \\
\hline $\mathrm{EP} 2$ & & & & & 0.810 & & & 0.811 \\
\hline EP3 & & & & & 0.805 & & & 0.802 \\
\hline EP4 & & & & & 0.788 & & & 0.780 \\
\hline EP5 & & & & & 0.780 & & & 0.792 \\
\hline SA1 & & & & & & 0.779 & & 0.792 \\
\hline SA2 & & & & & & 0.737 & & 0.921 \\
\hline SA3 & & & & & & 0.734 & & 0.776 \\
\hline SA4 & & & & & & 0.769 & & 0.813 \\
\hline RV1 & & & & & & & 0.821 & 0.828 \\
\hline RV2 & & & & & & & 0.882 & 0.952 \\
\hline RV3 & & & & & & & 0.833 & 0.827 \\
\hline RV4 & & & & & & & 0.854 & 0.836 \\
\hline RV5 & & & & & & & 0.842 & 0.851 \\
\hline
\end{tabular}

$T A$ tangibles, $R B$ reliability, $R P$ responsiveness, $A S$ assurance, $E P$ empathy

$S A$ lodger satisfaction, $R V$ lodger revisit intention

\subsection{Structural model assessment results}

A structural model may serve to represent the dependent relations between constructs (Hair et al. 2017; de Lima et al. 2019). This study therefore presents the structural model and the respective path coefficients in the combined layout depicted in Fig. 2. 
Table 4 Total variance explained

\begin{tabular}{lccccccc}
\hline Variables & \multicolumn{2}{l}{ Extraction sums of square loadings } & & \multicolumn{3}{l}{ Rotation sums of square loadings } \\
\cline { 2 - 3 } & Total & \% Variance & \% Cumulative & & Total & \% Variance & \% Cumulative \\
\hline TA & 13.792 & 44.492 & 44.492 & & 4.450 & 14.356 & 14.356 \\
RB & 3.168 & 10.221 & 54.713 & & 4.069 & 13.127 & 27.483 \\
RP & 2.721 & 8.776 & 63.489 & & 3.836 & 12.376 & 39.859 \\
AS & 2.492 & 8.040 & 71.529 & & 3.604 & 11.625 & 51.483 \\
EP & 1.565 & 5.050 & 76.579 & & 3.599 & 11.610 & 63.093 \\
SA & 1.249 & 4.028 & 80.607 & & 3.571 & 11.520 & 74.613 \\
RV & 1.224 & 3.948 & 84.555 & & 3.082 & 9.942 & 84.555 \\
\hline
\end{tabular}

Extraction method: Principal component analysis

$T A$ tangibles, $R B$ reliability, $R P$ responsiveness, $A S$ assurance, $E P$ empathy, $S A$ lodger satisfaction, $R V$ lodger revisit intention

Table 5 Correlations and quality criteria

\begin{tabular}{|c|c|c|c|c|c|c|c|c|}
\hline Constructs & & TA & RB & $\mathrm{RP}$ & AS & EP & SA & $\mathrm{RV}$ \\
\hline Tangibles (TA) & & 0.936 & & & & & & \\
\hline Reliabilities (RB) & & 0.447 & 0.852 & & & & & \\
\hline Responsiveness (RP) & & 0.204 & 0.547 & 0.901 & & & & \\
\hline Assurance (AS) & & 0.184 & 0.465 & 0.290 & 0.908 & & & \\
\hline Empathy (EP) & & 0.463 & 0.612 & 0.524 & 0.297 & 0.878 & & \\
\hline Satisfaction (SA) & & 0.419 & 0.569 & 0.469 & 0.531 & 0.504 & 0.879 & \\
\hline Revisit Intention (RV) & & 0.362 & 0.441 & 0.453 & 0.367 & 0.502 & 0.597 & 0.908 \\
\hline AVE & & 0.875 & 0.727 & 0.811 & 0.824 & 0.772 & 0.773 & 0.825 \\
\hline CR & & 0.965 & 0.928 & 0.945 & 0.949 & 0.944 & 0.930 & 0.959 \\
\hline KMO & & 0.933 & & & & & & \\
\hline Bartlett's test & $\begin{array}{l}\text { Approx. } \\
\text { Chi- } \\
\text { square }\end{array}$ & 8759.497 & & & & & & \\
\hline Of sphericity tests & $\mathrm{df}$ & 465 & & & & & & \\
\hline & sig. & 0.000 & & & & & & \\
\hline
\end{tabular}

\subsubsection{Hypotheses testing}

In this phase, we sought to analyze the results for the perceived satisfaction factors formed by lodgers in a quarantine hotel under a restricted service delivery regime. Results for the research hypotheses are summarized in Table 6. Consistent with the SEM result, the study model indicates a good fit for the data $(\times 2=567.696$, $\mathrm{df}=418, \times 2 / \mathrm{df}=1.358$. Goodness of Fit Index $(\mathrm{GFI})=0.914$; Comparative Fit Index $(\mathrm{CFI})=0.983$; Root Mean Square Error of Approximation $($ RMSEA $)=0.038)$. In the study hypotheses, the estimation of the standardized coefficients indicates that the path between each dimension was positive and significant. Particularly, 


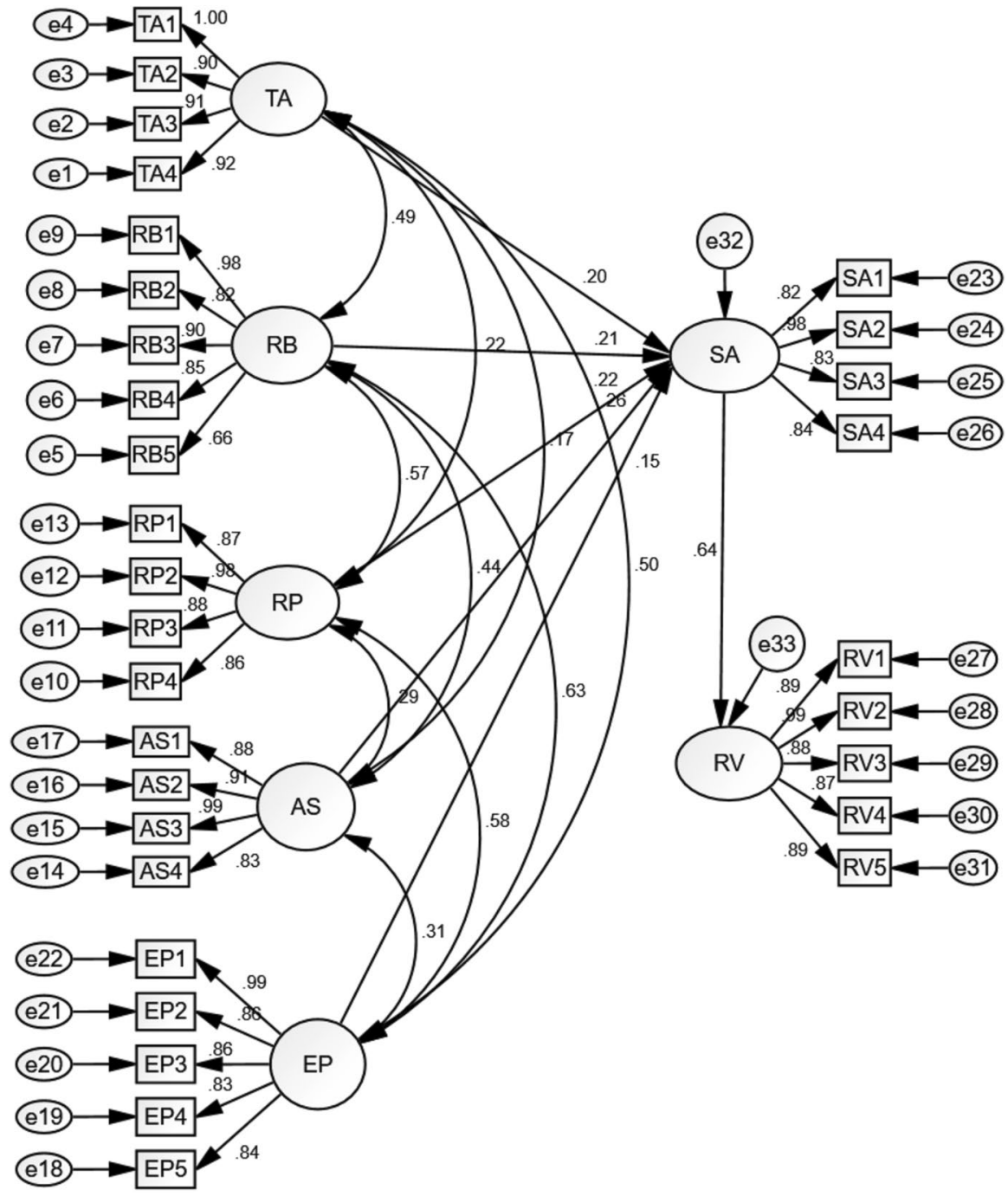

Fig. 2 Structural model. $T A$ tangibles, $R B$ reliability, $R P$ responsiveness, $A S$ assurance, $E P$ empathy, $S A$ lodger satisfaction, $R V$ lodger revisit intention

the relationships among the five constructs of service quality (tangibles, reliability, responsiveness, assurance, and empathy) and perceived satisfaction were significantly positive. Moreover, customer satisfaction was found to have a positive impact on lodger revisit intentions; thus, H1 to H6 are supported (Table 6).

As the number of service organizations increases and customers become more demanding and discriminating, service organizations face mounting pressure to ensure service quality in order to remain competitive (Nguyen et al., 2016). Important service factors include the intangibility of the service offering, the heterogeneity 
Table 6 Path coefficients and hypothesis results

\begin{tabular}{lllllll}
\hline Hypothesis & Paths & SE & C.R & Path coefficients & $\mathrm{p}$ & Results \\
\hline 1 & $\mathrm{TA} \rightarrow \mathrm{SA}$ & 0.044 & 3.685 & 0.202 & 0.000 & Supported \\
2 & $\mathrm{RB} \rightarrow \mathrm{SA}$ & 0.086 & 2.957 & 0.208 & 0.003 & Supported \\
3 & $\mathrm{RP} \rightarrow \mathrm{SA}$ & 0.061 & 3.569 & 0.218 & 0.000 & Supported \\
4 & $\mathrm{AS} \rightarrow \mathrm{SA}$ & 0.057 & 4.923 & 0.255 & 0.000 & Supported \\
5 & $\mathrm{EP} \rightarrow \mathrm{SA}$ & 0.062 & 2.305 & 0.152 & 0.021 & Supported \\
6 & $\mathrm{SA} \rightarrow \mathrm{RV}$ & 0.074 & 10.344 & 0.637 & 0.000 & Supported \\
\hline
\end{tabular}

Bias-corrected and accelerated bootstrap with 250 samples

$T A$ tangibles, $R B$ reliability, $R P$ responsiveness, $A S$ assurance, $E P$ empathy, $S A$ lodger satisfaction, $R V$ lodger revisit intention

of services, and their perishability - all of these factors indicate that service quality depends on many uncontrollable factors (Zeithaml et al. 2006). As encapsulated in Hypotheses 1 to 5, and in keeping with other related studies on this issue, the delivery of services positively influences lodgers' perceived satisfaction in a quarantine hotel, even though they are subjected to strict sanitation and quarantine regulations and restricted movement. Additionally, the result of Hypothesis 6 echoed the conclusions of Han et al. (2011) and Yang and Lau (2015); namely, both core services and service encounter performances significantly affected customer satisfaction, and their perceived satisfaction mediated the effects of service performances on switching intentions.

The findings of this study broaden our knowledge about the formation of hotel guest satisfaction by showing the influence of perceptions of restricted service delivery on satisfaction in terms of the service quality model. It is concluded that the perceived satisfaction of lodgers is consistent with the satisfaction they would feel with ordinary hotel operations. Our work reflects the growing importance of caring and meticulous service in terms of building guest satisfaction, which reinforces the theoretical connection between the constructs. Therefore, the need for hoteliers to determine and respect lodger's perceptions of service delivery is highlighted.

\subsubsection{Moderation effect testing}

To test Hypothesis 7, the moderating effect of a lodger's place of origin on the relationship between satisfaction and revisit intention was examined following González-Romá et al. (2002) and Cheng et al. (2019a, b). The moderating effect is divided into three models. Model 1 includes independent variables (satisfaction). Model 2 adds the moderating variable (place of origin) based on Model 1, and Model 3 adds an interaction term (satisfaction and place of origin) on the basis of Model 2.

For Model 1, the purpose is to study the influence of the independent variable (satisfaction) on the dependent variable (revisit intention) without considering the interference of a lodger's place of origin. Table 7 shows that satisfaction 


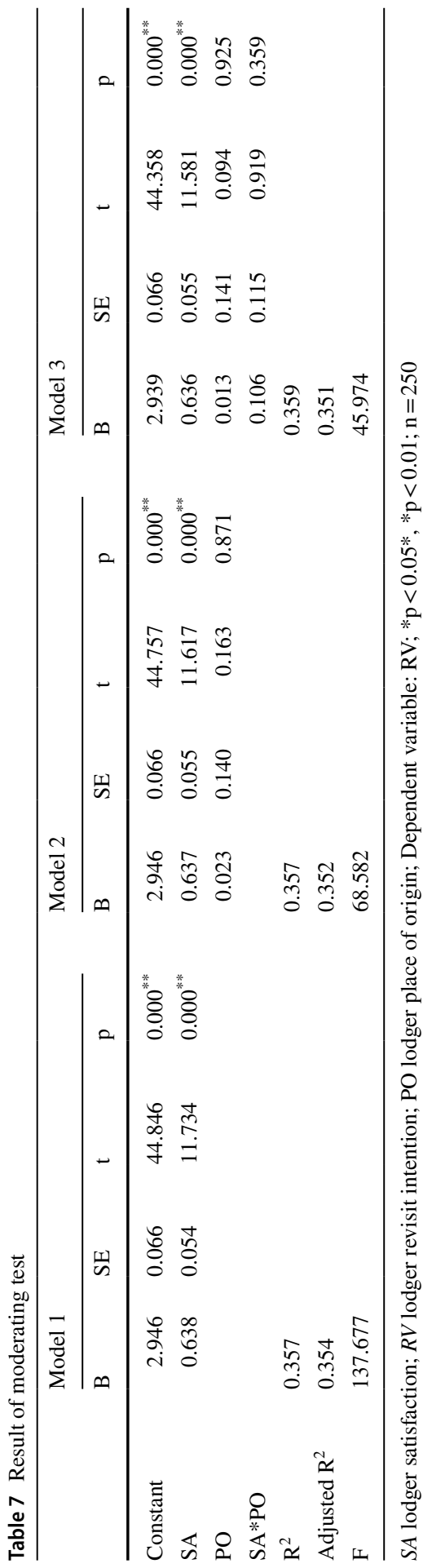


is significant $(\mathrm{t}=11.734, p=0.000<0.05)$. This means that satisfaction will have a significant influence on revisit intention.

The moderation effect can be checked in two ways. The first is to check the significance of the change in the F value from Model 2 to Model 3. The second is to check the significance of the interaction term in Model 3. In this study, we used the second way to analyze the moderation effect in order to verify whether lodger's place of origin strengthen perceived satisfaction to revisit intention.

It can be seen from Table 7 that the interaction term between satisfaction and place of origin does not show significance $(t=0.919, p=0.359>0.05)$. In other words, Hypothesis 7 is not supported, although a lodger's perceived satisfaction has an influence on his/her revisit intention in terms of Model 1; for different levels of the moderating variable (lodger's place of origin), the impact range remains the same.

\section{Discussions}

This study has several important theoretical and managerial insights for hotel hospitality. Consistent with Cheng et al. (2019a, b), del Rio-Lanza et al. (2009), and McColl et al. (2003), no difference in perception between native and non-native lodgers is evident. Similar to an ordinary hotel, a guest's service perception in a quarantine hotel positively impacts customer satisfaction. This result shows that customers had a strong service perception of the service quality model during the 14-day quarantine that may affect their revisit intention. Thus, lodgers' satisfaction is strongly correlated with their perceptions of service, and thus exhibit revisit intentions. Obvious service problems, the most disagreed questionnaire item, in the surveyed hotels are listed and analyzed to understand the difference between satisfaction and revisit intention.

According to the mean scores of each variable item in Appendix, we can find some interesting implications from the results of this study. Respondents indicated that guests were dissatisfied with timely temperature checks and demand for food/ service items. In a quarantine hotel, several room guests passively accept services several times a day, for example, waiting for meals and getting their temperature checked. Guests' movement is limited and their daily schedules are also restricted. Thus, they are anxious about the uncertainty arising from the inability to adjust one's biological clock when confined to a limited space. Therefore, on-time service becomes a measure of the quality in a quarantine hotel.

Numerous respondents were concerned about the mandatory hotel instructions. Ambiguous instructions led to communication errors and severely damaged the quarantine hotel's image regarding service. Service receivers emphasize fairness; that is, they believe that if they abide by the rules, they deserve the services, rather than being discriminated from others. However, most service industry managers give preferential treatment to customers with large contributions to stimulate shortterm profits or to enhance performance, although this approach is detrimental to a quarantine hotel. 
Two other questionnaire items were significant: in the "Assurance" dimension, namely, "Feeling secure and safe in receiving care and during communication with staff" and "Feeling assured when receiving services." Several travelers find the quarantine period an unforgettable experience, but such experience is ambiguous. An average person neither stays in a hotel for two weeks as they are usually temporary lodging, nor does one experience travel quarantine. If the room guest encounters a kind and courteous service staff, the guest would have a positive impression about the quarantine hotel. Conversely, if the guest has had unpleasant interactions, the resulting negative impression lasts a lifetime, and the guest would avoid future stay in this hotel. The service staff at a quarantine hotel comprises hotel employees, medical workers from the government epidemic prevention department, and some volunteers; however, the staff in protective gear prevents most guests from discerning or recognizing the staff from different sources, particularly because of contactless services. Obviously, the guests will assume that all staff members are employees of the quarantine hotel. Impolite manners, unprofessional answers, or unreliable measures lead to unease or even trepidation among lodgers.

The dimensions of "Tangibles" and "Empathy" had no common problematic items for the four surveyed quarantine hotels, perhaps because lodgers had fewer demands and options regarding the hotel's appearance and basic facilities. On arrival, most lodgers were randomly assigned to quarantine hotels after a preliminary physical examination at the port of entry. However, they did not experience a lack of empathy because the quarantine hotel strictly implemented contactless services. Nevertheless, the two dimensions were critical for linking satisfaction and revisit intention, consistent with the statistical results showing a positive relationship.

These service dimensions have several managerial implications. First, lodgers at a quarantine hotel emphasize the perception of service reliability, responsiveness, and assurance during the stay. Hotel management and its team should focus on the importance of "soft skills" of services because it reinforces the hotel's brand image and improves customer's revisit intention (Sisson and Adams 2013). Soft skills are behaviors that directly impact guest impressions and feelings and result in positive, negative, or indifferent reactions that include verbal and nonverbal communication styles, attitudes, teamwork, awareness, authenticity, empathy, and even leadership. As a showcase the personal side of service, such as greeting guests, responsiveness to their needs and requests, and the care taken at each touch point, attentiveness, and solicitude (Singh and Jaykumar 2019). Soft skills indicate how team members use their attitudes, behaviors, and verbal skills to interact with guests (Hurrell 2016). Hotel requires employees' having interpersonal or personal skills, the development of such soft skills has become one of the major topics among hospitality employers due its nature of hospitality (Weber et al. 2020). Therefore, soft skills are critical for customer satisfaction under strict contactless service in a quarantine hotel.

Secondly, attitude toward service provision between hotelier and guest has also a huge gap, for example, the quarantine hotel management and lodgers had divergent views regarding the service provision; management believed that hotel residence instructions are important, but not critical, whereas guests in fact focused on the clarity of the quarantine hotel residence instructions. Hotel managers must analyze and evaluate quality and quantity of services for various situations to identify the 
gaps between customer perception and expectation enabling them to judiciously remove such gaps, which ultimately helps in retaining valued customers (Sunil et al. 2018; Cheng et al. 2019a, b).

Finally, consistent with the study observation, a qualified hotel should satisfy ventilation conditions to be assigned for quarantine use (GNPHO 2020; TPDIT 2020). General hotel operations differ from quarantine hotels. Quarantine hotel service staff in must be specifically trained and they must strictly abide by the stipulated precautions, such as wear goggles, mask, and protective gear; maintain at least 1-m distance from the people in quarantine; and follow guidelines about hand washing and respiratory hygiene, especially following contact with respiratory secretions, before eating, and after using the lavatory. Operational challenges in conflicting epidemic prevention codes and hotel work specifications and managing the hotel service and epidemic prevention staff because of the closed and long working conditions should be addressed. Moreover, the hotel's reputation is affected. Several regions are reporting numerous confirmed COVID-19 cases from abroad. These regions cannot avoid negative labels from society. The quarantine hotels are stigmatized and labeled "hotels for sick people." Furthermore, expectations of service by guests in quarantine for 14 days in a hotel are heightened, thus leading to reduced perception of hospitality, especially if they are paying for the services. A disappointed customer could express his or her dissatisfaction by word-of-mouth to family and friends or posting on social media. Therefore, the hotel's reputation and customer base are severely damaged.

In summary, a satisfied customer with the perceived image of the quarantine hotel would revisit the hotel. Lodgers' positive opinion about their hotel quarantine period increases the probability of their revisit intention and desire. Revisit intention is an extension of satisfaction rather than leading to the decision of revisit. For hoteliers, good soft skills increase the level of hospitality and improve customer satisfaction. Although the place of origin has no moderating role in the relationship between satisfaction and customer revisit intention, it reflects the views on satisfaction and revisit intentions regardless of the place of origin. Hoteliers continuously improve service quality and improve customer satisfaction based on this factor for effective customer retention.

\section{Conclusion}

The present study has gone beyond the findings of the current literature that the study results focused on the quality of hospitality under service restriction by external factors in quarantine hotels and suggested that service perception impacted lodgers where each dimension of the service quality model with five major constructs of tangibles, reliability, responsiveness, assurance, and empathy, favors customer satisfaction and their revisit intention. Moreover, customer satisfaction supports lodger revisit intention in quarantine hotel services, indicating that recognition of customers' service perceptions is crucial for delivering superior service because these 
perceptions are indicators of the performance standards that customers use to assess service quality.

A few services affect the perceptions and satisfactions of quarantine hotel guests during prolonged confinement to a limited space. This empirical study provides the managerial insight that hospitality industry managers should consider a quarantine hotel guest's viewpoint rather than act immutable as in ordinary hotel hospitality. To encourage customers to revisit the hotel during normal times, the services provided must meet their promise, which would satisfy the customer and increase their revisit intention.

Hence, quarantine hoteliers understand that certain factors affect their guests' perceptions, but they were not fully prepared to provide some unique services as a quarantine hotel. These unexpected services included coordination with the epidemic prevention department, education and training of service personnel, and provision of clear residential instructions.

This study has several limitations. First, this study is limited to hotels in quarantine use at Mainland China and Taiwan, so the findings may not fully reflect the precise hospitality problem. Second, this study only briefly describes the quarantine department regulations and its staff intervention in quarantine hotel's daily reception work rather than in-depth exploration of such intervention affects customer service satisfaction and subsequent revisit intention. To improve the existing theory, future research should examine the relationships between service satisfaction and revisit intention toward quarantine hotel once normalcy is restored.

Another limitation of this study is the sample of selected demographic variables. More than $99 \%$ of the respondents were quarantined in Mainland China and Taiwan. These regions have high cultural homogeneity so it does not reflect the obvious differences in satisfaction and willingness to revisit. Future research should focus on samples in regions with strong social and cultural heterogeneity. Various cultures have a different impact on service perception and assessment. Therefore, tourism service gaps between perceptions and satisfaction at quarantine hotels in other regions should be investigated in future research, or a cross-country sample should compare the prevalent satisfactions among quarantined hotel guests of different cultures.

Supplementary Information The online version contains supplementary material available at https://doi. org/10.1007/s11628-021-00445-w.

Acknowledgements The authors thank the anonymous referees for their useful suggestions. We also would like to appreciate Mr. Mark C. Birmingham of Winner Hospitality Consulting Group for his research object contact and coordinate. This work was funded by Talent Support Project of Guangdong University of Petrochemical Technology (Ref. No. 702-519197).

\section{References}

Aguiar-Quintana T, Moreno-Gil S, Picazo-Peral P (2016) How could traditional travel agencies improve their competitiveness and survive? A qualitative study in Spain. Tour Manag Perspect 20:98-108. https://doi.org/10.1016/j.tmp.2016.07.011 
Ahmad SZ, Ahmad N, Papastathopoulos A (2019) Measuring service quality and customer satisfaction of the small- and medium-sized hotels (SMSHs) industry: lessons from United Arab Emirates (UAE). Tour Rev 74:349-370. https://doi.org/10.1108/TR-10-2017-0160

Ahn J, Kwon J (2020) Green hotel brands in Malaysia: perceived value, cost, anticipated emotion, and revisit intention. Curr Issues Tour 23:1559-1574. https://doi.org/10.1080/13683500.2019.1646715

Akhbar MM, Parvez N (2009) Impact of service quality, trust, and customer satisfaction on customer loyalty. ABAC Journal 29:24-38

Al-Ababneh MM, Masadeh MA, Al-Shakhsheer FJ, Habiballah MMA (2018) The impact of internal service quality on job satisfaction in the hotel industry. Res in Hos Manag 8:55-62. https://doi.org/10. $1080 / 22243534.2018 .1501182$

Al-Gharaibah O (2020) Customer retention in five-star hotels in Jordan: The mediating role of hotel perceived value. Manag Sci Lett 10:3949-3956. https://doi.org/10.5267/j.ms1.2020.7.015

Ali F, Amin M (2014) The effect of physical environment on customer's emotions, satisfaction and behavioural loyalty. J Glob Bus Adv 7:249-266. https://doi.org/10.1504/JGBA.2014.064109

Ali M, Raza SA (2019) Service quality perception and customer satisfaction in Islamic banks of Pakistan: the modified SERVQUAL model. Total Qual Manag Bus Excell 28:559-577

Ali F, Dey BL, Filieri R (2015) An assessment of service quality and resulting customer satisfaction in Pakistan International Airlines. Int J Qual Reliab Manag 32:486-502. https://doi.org/10.1108/ IJQRM-07-2013-0110

Ali F, Ryu K, Hussain K (2016) Creative tourists' experience, memories, satisfaction and behavioural intentions. J Travel Tour Mark 33:85-100. https://doi.org/10.1080/10548408.2015.1038418

Ali F, Hussain K, Konar R, Jeon HM (2017) The effect of technical and functional quality on guests' perceived hotel service quality and satisfaction: A SEM-PLS analysis. J Qual Assur Hosp Tour 18:354-378. https://doi.org/10.1080/1528008X.2016.1230037

American Hotel \& Lodging Association (AHLA) (2000) COVID19 impact on hotel industry, https:// www.ahla.com/covid-19s-impact-hotel-industry

Amfani-Joe CE, Bahagu A, Osagede E (2018) Consumer perception and satisfaction of hotel services in Lafia, Nasarawa State, Nigeria. Asian J Adv Res Rep 1:1-11. https://doi.org/10.9734/ajarr/2018/ v1i313077

Amin M, Yahya Z, Ismayatim WFA, Nasharuddin SZ, Kassim E (2013) Service quality dimension and customer satisfaction: An empirical study in the Malaysian hotel industry. Serv Market Q 34:115125. https://doi.org/10.1080/15332969.2013.770665

Arifin WN, Yusoff MSB (2016) Confirmatory factor analysis of the Universiti Sains Malaysia emotional quotient inventory among medical students in Malaysia. SAGE Open 6:1-9. https://doi.org/10. $1177 / 2158244016650240$

Armstrong G, Kotler P (2009) Marketing: An Introduction, 5th edn. Prentice-Hall, NJ

Assaker G, O'Connor P, El-Haddad R (2020) Examining an integrated model of green image, perceived quality, satisfaction, trust, and loyalty in upscale hotels. J Hospit Market Manag 29:934-955. https://doi.org/10.1080/19368623.2020.1751371

Aydin S, Özer G (2005) The analysis of antecedents of customer loyalty in the Turkish mobile telecommunication market. Eur J Marketing 39:910-925. https://doi.org/10.1108/03090560510601833

Baek J, Choe Y, Ok CM (2019) Determinants of hotel guests' service experiences: an examination of differences between lifestyle and traditional hotels. J Hosp Mark Manag 29:88-105. https://doi.org/ $10.1080 / 19368623.2019 .1580173$

Bailey D (2021) Hotel quarantine: isolation and brown paper bags, February 27 BBC News. Retrieved from https://www.bbc.com/news/uk-56212665

Ban HJ, Choi H, Choi EK, Lee S, Kim HS (2019) Investigating key attributes in experience and satisfaction of hotel customer using online review data. Sustainability 11:6570. https://doi.org/10.3390/ su 11236570

Basfrinci C, Mitra A (2015) A cross cultural investigation of airlines service quality through integration of Servqual and the Kano model. J Air Transp Manag 42:239-248. https://doi.org/10.1016/j.jairt raman.2014.11.005

Bawa MIM (2017) Reliability and validity test for employee rewards \& customer service training and service recovery performance: mediation of organizational commitment in hotel industry. Res. Exp. 5:32-37

Bitner MJ (1992) Servicescapes: the impact of the physical surroundings on customers and employees. J Mark 56:57-71. https://doi.org/10.1177/002224299205600205 
Bitner MJ, Hubbert AR (1994) Encounter satisfaction versus overall service satisfaction versus quality. In: Rust RT, Oliver RL (eds) Services quality: New directions in theory and practice. CA Sage Publications, Thousand Oaks

Bonera M, Corvi E, Codini AP, Ma R (2017) Does nationality matter in eco-behaviour? Sustainability 9:1694. https://doi.org/10.3390/su9101694

Borghi S, Mainardes E, Silva É (2016) Expectations of higher education students: a comparison between the perception of student and teachers. Tert Educ Manag 22:171-188. https://doi.org/10.1080/ 13583883.2016.1188326

Bravo R, Martinez E, Pina JM (2019) Effects of service experience on customer responses to a hotel chain. Int J Contemp Hosp Manag 31:389-405. https://doi.org/10.1108/IJCHM-09-2017-0569

Breitsohl J, Garrod B (2016) Assessing tourists' cognitive, emotional and behavioural reactions to an unethical destination incident. Tour Manag 54:209-220. https://doi.org/10.1016/j.tourman.2015. 11.004

Brown TJ, Churchill GA, Peter JP (1993) Improving the measurement of service quality. J Retail 69:127-139

Brown G, Smith A, Assaker G (2016) Revisiting the host city: An empirical examination of sport involvement, place attachment, event satisfaction and spectator intentions at the London Olympics. Tour Manage 55:160-172. https://doi.org/10.1016/j.tourman.2016.02.010

Byrne BM (2016) Structural equation modeling with AMOS: basic concepts, applications, and programming, 3rd edn. Routledge, New York \& London

Chen Z, Dubinsky AJ (2003) A conceptual model of perceived customer value in e-commerce: A preliminary investigation. Psychol Mark 20:323-347. https://doi.org/10.1002/mar.10076

Cheng BL, Rashid MZA (2013) Service quality and the mediating effect of corporate image on the relationship between customer satisfaction and customer loyalty in the Malaysian hotel industry. Gadjah Mada Int J Bus 15:99-112

Cheng YS, Kuo NT, Chang KC, Hu SM (2019) Integrating the Kano model and IPA to measure quality of museum interpretation service: a comparison of visitors from Taiwan and Mainland China. Asia Pacific J Tour Res 24:483-500. https://doi.org/10.1080/10941665.2019.1591474

Cheng BL, Gan CC, Imrie BC, Mansori S (2019a) Service recovery, customer satisfaction and customer loyalty: Evidence from Malaysia's hotel industry. Int J Qual Serv Sci 11:187-203. https://doi.org/ 10.1108/IJQSS-09-2017-0081

Choi H, Kandampully J (2019) The effect of atmosphere on customer engagement in upscale hotels: An application of SOR paradigm. Int J Hosp Manag 77:40-50. https://doi.org/10.1016/j.ijhm.2018.06. 012

Collins A, Medhekar A, Wong HY, Cobanoglu C (2019) Factors influencing outbound medical travel from the USA. Tour Rev 74:463-479. https://doi.org/10.1108/TR-06-2018-0083

Cronin JJ Jr, Brady MK, Hult GTM (2000) Assessing the effects of quality, value, and customer satisfaction on consumer behavioral intentions in service environments. J Retail 76(2):193-218. https:// doi.org/10.1016/S0022-4359(00)00028-2

Davies C (2021) Quarantine hotel rooms are 'like a prison'. February 17 BBC News. Retrieved from https://www.bbc.com/news/business-56095362

Department of Information and Tourism, Taipei City Government (TPDIT) (2020) Taipei City Hotel Epidemic Prevention Manual. https://www.tpedoit.gov.taipei/News_Content.aspx?n=133DDB9056 1F19A8\&sms=78D644F2755ACCAA\&s=68538971AE89B37C (In Chinese)

de Lima MM, Mainardes EW, Rodrigues RG (2019) Tourist expectations and perception of service providers: a Brazilian perspective. Serv Bus 14:131-166. https://doi.org/10.1007/s11628-019-00406-4

Dedeoglu BB, Demirer H (2015) Differences in service quality perceptions of stakeholders in the hotel industry. Int J Contemp Hosp Manag 27:130-146. https://doi.org/10.1108/IJCHM-08-2013-0350

del Río-Lanza AB, Vázquez-Casielles R, Díaz-Martín AM (2009) Satisfaction with service recovery: perceived justice and emotional responses. J Bus Res 62:775-781. https://doi.org/10.1016/j.jbusres. 2008.09.015

Donthu N, Yoo B (1998) Cultural influences on service quality expectations. J Serv Res 1:178-186. https://doi.org/10.1177/109467059800100207

Drinkert A, Singh N (2017) An investigation of American medical tourists' posttravel experience. J Hosp Mark Manag 26:335-346. https://doi.org/10.1080/19368623.2017.1241199

El-Adly MI (2019) Modelling the relationship between hotel perceived value, customer satisfaction, and customer loyalty. J Retail Consum Serv 50:322-332. https://doi.org/10.1016/j.jretconser.2018.07. 007 
El-Adly MI, Eid R (2015) Measuring the perceived value of malls in a non-Western context: the case of the UAE. Int J Retail Distrib Manag 43:849-869. https://doi.org/10.1108/IJRDM-04-2014-0045

Etemad-Sajadi R, Rizzuto D (2013) The antecedents of consumer satisfaction and loyalty in fast food industry: a cross-national comparison between Chinese and Swiss consumers. Int J Qual Reliab Manag 30:780-798. https://doi.org/10.1108/IJQRM-May-2012-0069

Fornell C, Larcker DF (1981) Evaluating structural equation models with unobservable variables and measurement error. J Mark Res 18:39-46. https://doi.org/10.2307/3151312

Foroudi P, Gupta S, Kitchen P, Foroudi MM, Nguyen B (2016) A framework of place branding, place image, and place reputation. Qual Market Res Int J 19:241-264. https://doi.org/10.1108/ QMR-02-2016-0020

Fredrick OJ (2019) Hotel standardization and classification system in Kenya: A quality assurance approach. African J Hosp Tour Leis 8:1-22

Fullinfaw NG, Sunil MP (2019) The impact of total quality management practices on key performance indicators of star hotels. Int J Adv Sci Res Manag. 4:98-109

Gallarza MG, Gil Saura I, Arteaga Moreno F (2013) The quality-value-satisfaction-loyalty chain: relationships and impacts. Tour Rev 68:3-20. https://doi.org/10.1108/16605371311310048

Gilbert D, Wong RKC (2003) Passenger expectations and airline services: a Hong Kong based study. Tour Manag 24:519-532. https://doi.org/10.1016/S0261-5177(03)00002-5

Gonzalez ME, Mueller RF, Mack RW (2008) An alternative approach in service quality: an e-banking case study. Qual Manag J 15:41-59. https://doi.org/10.1080/10686967.2008.11918055

González-Romá V, Peiro JM, Tordera N (2002) An examination of the antecedents and moderator influences of climate strength. J Appl Psychol 87:465-473. https://doi.org/10.1037/0021-9010.87.3.465

Grönroos C (1984) A Service Quality Model and its Marketing Implications. Eur J Mark 18:36-44. https://doi.org/10.1108/EUM0000000004784

Guadagnoli E, Velicer WF (1988) Relation of sample size to the stability of component patterns. Psychol Bull 103:265-275. https://doi.org/10.1037/0033-2909.103.2.265

Guix M, Bonilla-Priego M, Font X (2018) The process of sustainability reporting in international hotel groups: an analysis of stakeholder inclusiveness, materiality and responsiveness. J Sustain Tour 26:1063-1084. https://doi.org/10.1080/09669582.2017.1410164

Hafeez S, Muhammad B (2012) The impact of service quality, customer satisfaction and loyalty Programs on customer's loyalty: evidence from banking sector of Pakistan's. Int J Bus Soc Res 3:200-209

Hair JF, Hult GTM, Ringle C, Sarstedt M (2017) A primer on partial least squares structural equation modeling (PLS-SEM), 2nd edn. Sage, Los Angeles/LondonlNew DelhilSingaporelWashington, Dc

Han H, Kim W, Hyun SS (2011) Switching intention model development: Role of service performances, customer satisfaction, and switching barriers in the hotel industry. Int J Hosp Manag 30:619-629. https://doi.org/10.1016/j.ijhm.2010.11.006

Haque A, Sarwar A, Azam SMF, Yasmin F (2014) Total quality management practices in the Islamic banking industry: comparison between Bangladesh and Malaysian Islamic bank. Int J Ethics Soc Sci 2:5-18

Haur CH, Azam Khatibi A, SMF, (2017) Antecedents of consumers' perception towards online advertising in Malaysia: The structure equation modeling Approach. Eur J Manag Mark Stud 2:15-30. https://doi.org/10.46827/ejmms.v0i0.205

Hellén K, Gummerus J (2013) Re-investigating the nature of tangibility/intangibility and its influence on consumer experiences. J Serv Manag 24:130-150. https://doi.org/10.1108/09564231311323935

Henseler J (2018) Partial least squares path modeling: quo vadis? Qual Quant 52:1-8. https://doi.org/10. 1007/s11135-018-0689-6

Hew WWL, Goh GGG, Yong MK (2016) Translating information and awareness of green hotels' green tech practices into lodgers' satisfaction and green trust into lodgers' loyalty. Info an Intl Interdiscip J 19:3173-3178

Hu H, Kandampully J, Juwaheer TD (2009) Relationships and impacts of service quality, perceived value, customer satisfaction, and image: An empirical study. Serv Ind J 29:111-125. https://doi. org/10.1080/02642060802292932

Huang SS, Crotts J (2019) Relationships between Hofstede's cultural dimensions and tourist satisfaction: A cross-country cross-sample examination. Tour Manag 72:232-241. https://doi.org/10.1016/j. tourman.2018.12.001

Hult GTM, Hair JF Jr, Proksch D, Sarstedt M, Pinkwart A, Ringle CM (2018) Addressing endogeneity in international marketing applications of partial least squares structural equation modeling. J Intl Mark 26:1-21. https://doi.org/10.1509/jim.17.0151 
Hultman M, Papadopoulou C, Oghazi P, Opoku R (2021) Branding the hotel industry: The effect of stepup versus step-down brand extensions. J Bus Res 124:560-570. https://doi.org/10.1016/j.jbusres. 2020.10 .047

Hurrell SA (2016) Rethinking the soft skills deficit blame game: employers, skills withdrawal and the reporting of soft skills gaps. Hum Relat 69:605-628. https://doi.org/10.1177/0018726715591636

HVS Global Hospitality Services (2020) Impact of covid-19 on Chinese hotel industry. https://www. hospitalitynet.org/file/152008810.pdf

Hwang J, Han H (2016) A model of brand prestige formation in the casino industry. J Travel Tour Mark 33:1106-1123. https://doi.org/10.1080/10548408.2015.1084977

Jaakkola E, Helkkula A, Aarikka-Stenroos L, Dube A (2015) Service experiences beyond the direct use: indirect customer use experiences of smartphone apps. J Serv Manag 26:224-248. https://doi.org/ 10.1108/JOSM-11-2014-0308

Jalilvand MR, Samiei N, Dini B, Manzari PY (2012) Examining the structural relationships of electronic word of mouth, destination image, tourist attitude toward destination and travel intention: An integrated approach. J Dest Mark Manage 1:134-143. https://doi.org/10.1016/j.jdmm.2012.10.001

Jasinskas E, Streimikiene D, Svagzdiene B, Simanavicius A (2016) Impact of hotel service quality on the loyalty of customers. Econ Res-Ekon Istraž 29:559-572. https://doi.org/10.1080/1331677X.2016. 1177465

Jazira A, Kamaruzaman J, Faliza MA, Sairah S, Zetty M, Khazainah K, Mushaireen M (2011) Accessing hotel responsiveness towards guest's email query: cases in Malaysia. World Appl Sci J 12:14-18

Jin NP, Lee S, Lee H (2013) The effect of experience quality on perceived value, satisfaction, image and behavioral intention of water park patrons: New versus repeat visitor. Int J Tour Res 17:82-95. https://doi.org/10.1002/jtr.1968

Johnston R (1995) The determinants of service quality: satisfiers and dissatisfiers. Int J Serv Ind Manag 6:53-71. https://doi.org/10.1108/09564239510101536

Jridi K, Klouj R, Bakini FE (2014) Experiential perceived quality of a tourist destination: effects on satisfaction and loyalty of the tourist: case: Saharan tourism in Tunisia. SSRN. https://doi.org/10.2139/ ssrn.2482544

Kandampully J, Suhartanto D (2000) Customer loyalty in the hotel industry: The role of customer satisfaction and image. Int J Contemp Hosp Manag 12:346-351. https://doi.org/10.1108/0959611001 0342559

Kaplan MD, Yurt O, Guneri B, Kurtulus K (2010) Branding places: applying brand personality concept to cities. Eur J Mark 44:1286-1304. https://doi.org/10.1108/03090561011062844

Keng CJ, Huang TL, Zheng LJ, Hsu MK (2007) Modeling service encounters and customer experiential value in retailing. Int J Serv Ind Manag 18:349-367. https://doi.org/10.1108/09564230710778137

Khan GF, Sarstedt M, Shiau WL, Hair JF, Ringle CM, Fritze MP (2019) Methodological research on partial least squares structural equation modeling (PLS-SEM). Internet Res. https://doi.org/10.1108/ IntR-12-2017-0509

Kim HW, Chan HC, Gupta S (2007) Value-based adoption of mobile internet: an empirical investigation. Decis Support Syst 43:111-126. https://doi.org/10.1016/j.dss.2005.05.009

Kinderis R, Žalys L, Žalienė I (2011) Paslaugų kokybės vertinimas viešbučių versle (Evaluation of service quality in the hotel business). Ekono Vady: aktu pers 1:86-100. https://etalpykla.lituanisti kadb.lt/object/LT-LDB-0001:J.04 2011 1367174927148/J.04 2011 1367174927148.pdf ～(In Lithuanian)

Lam T, Zhang HQ (1999) Service quality of travel agents: the case of travel agents in Hong Kong. Tour Manage 20:341-349. https://doi.org/10.1016/S0261-5177(98)00118-6

Lee HS (2013) Major moderators influencing the relationships of service quality, customer satisfaction and customer loyalty. Asian Soc Sci 9:1-11. https://doi.org/10.5539/ass.v9n2p1

Lee S, Jeong M (2012) Effects of e-servicescape on consumers' flow experiences. J Hosp Tour Technol 3:47-59. https://doi.org/10.1108/17579881211206534

Lee S, Sun KA, Wu L, Xiao Q (2018) A moderating role of green practices on the relationship between service quality and customer satisfaction: Chinese hotel context. J China Tour Res 14:42-60. https://doi.org/10.1080/19388160.2017.1419897

Leong VS, Hibbert S, Ennew C (2018) Communicating value to enhance service visualization. J Serv Mark 32:645-656. https://doi.org/10.1108/JSM-04-2017-0114

Li W, Yu S, Pei H, Zhao C, Tian B (2017) A hybrid approach based on fuzzy AHP and 2-tuple fuzzy linguistic method for evaluation in-flight service quality. J Air Transp Manag 60:49-64. https://doi. org/10.1016/j.jairtraman.2017.01.006 
Liat CB, Mansori S, Huei CT (2014) The associations between service quality, corporate image, customer satisfaction, and loyalty: Evidence from the Malaysian hotel industry. J Hosp Mark Manag 23:314-326. https://doi.org/10.1080/19368623.2013.796867

Lu JL, Ling FI (2008) Cross-cultural perspectives regarding service quality and satisfaction in Chinese cross-strait airlines. J Air Transp Manag 14:16-19. https://doi.org/10.1016/j.jairtraman. 2007.08.002

Malhotra NK, Ulgado FM, Agarwal J, Shainesh G, Wu L (2005) Dimensions of service quality in developed and developing economies: multi-country cross-cultural comparisons. Int Mark Rev 22:256-278. https://doi.org/10.1108/02651330510602204

Manna R, Cavallone M, Ciasullo MV, Palumbo R (2020) Beyond the rhetoric of health tourism: shedding light on the reality of health tourism in Italy. Curr Issues Tour 23:1805-1819. https://doi. org/10.1080/13683500.2019.1650726

Markovic S, Raspor S (2010) Measuring perceived service quality using servqual: A case study of the Croatian hotel industry. Mngmt Univ Primorska Fac Mgt Kop 5:195-209

Martín JC, Rudchenko V, Sánchez-Rebull MV (2020) The role of nationality and hotel class on guests' satisfaction. A fuzzy-TOPSIS approach applied in Saint Petersburg. Adm Sci 10:68. https://doi.org/10.3390/admsci10030068

Mathwick C, Malhotra N, Rigdon E (2001) Experiential value: conceptualization, measurement and application in the catalog and Internet shopping environment. J Retail 77:39-56. https://doi.org/ $10.1016 / \mathrm{S} 0022-4359(00) 00045-2$

McColl-Kennedy JR, Sparks BA (2003) Application of fairness theory to service failures and service recovery. J Serv Res 5:251-266. https://doi.org/10.1177/1094670502238918

Mohamad HAD, Ab Yazid MS, Khatibi A, Azam SF (2017) Service quality, customer satisfaction and customer loyalty of the hotel industry in United Arab Emirates (UAE): A measurement model. Eur J Manag Mark Stu 2:1-26. https://doi.org/10.5281/zenodo.1066572

Molina A, Moliner C, Martínez-Tur V, Cropanzano R, Peiró JM (2015) Unit-level fairness and quality within the health care industry: a justice-quality model. Eur J Work Organ Psychol 24:627-644. https://doi.org/10.1080/1359432X.2014.960401

Mulyana A, Prayetno S (2018) Determinants of customer satisfaction and it's implication on customer loyalty of budget hotel in DKI Jakarta. Intl Rev Manag Mark 8:1-7. https://doi.org/10.32479/ irmm.7144

Myo YN, Khalifa GS, Aye TT (2019) The impact of service quality on customer loyalty of Myanmar hospitality industry: the mediating role of customer satisfaction. Int J Hum Resour Manag $3: 1-11$

Narangajavana Y, Callarisa Fiol LJ, Moliner Tena MÁ et al (2017) The influence of social media in creating expectations. An empirical study for a tourist destination. Ann Tour Res 65:60-70. https://doi.org/10.1016/j.annals.2017.05.002

National Public Health Organization of Greece (GNPHO) (2020) COVID-19 - Advice for hotels in quarantine. https://eody.gov.gr/en/covid-19-advice-for-hotels-in-quarantine/

Nguyen B, Yu X, Gupta MTC, S, (2016) Critical brand innovation factors: understanding innovation and market performance in the Chinese high-tech service industry. J Bus Res 69:2471-2479. https://doi.org/10.1016/j.jbusres.2016.02.016

Nunkoo R, Teeroovengadum V, Ringle CM, Sunnassee V (2020) Service quality and customer satisfaction: The moderating effects of hotel star rating. Int J Hosp Manag 91:102414. https://doi. org/10.1016/j.ijhm.2019.102414

Oliver RL (1980) A cognitive model of the antecedents and consequences of satisfaction decisions. J Mark Res 17:460-469. https://doi.org/10.2307/3150499

Padma P, Ahn J (2020) Guest satisfaction \& dissatisfaction in luxury hotels: An application of big data. Int j Hosp Manag 84:102318. https://doi.org/10.1016/j.ijhm.2019.102318

Pan WT (2014) Using data mining for service satisfaction performance analysis for mainland tourists in Taiwan. Int J Technol 3:31-44. https://doi.org/10.1504/IJTM.2014.059236

Pan X, Moreira JP (2018) Outbound medical tourists from China: An update on motivations, deterrents, and needs. Int J Healthc Manag 11:217-224. https://doi.org/10.1080/20479700.2018. 1425277

Parasuraman A, Zeithaml VA, Berry LL (1985) A conceptual model of service quality and its implications for future research. J Mark 49:41-50

Parasuraman A, Zeithaml V, Berry LL (1988) SERVQUAL: a multiple-item scale for measuring consumer perceptions of service quality. J Retail 64:12-40 
Pereira HG, Salgueiro MF, Rita P (2017) Online determinants of e-customer satisfaction: application to website purchases in tourism. Serv Bus 11:375-403. https://doi.org/10.1007/s11628-016-0313-6

Pizam A, Sussmann S (1995) Does nationality affect tourist behavior? Ann Tour Res 22(4):901-917

Prayag G, Lee C (2019) Tourist motivation and place attachment: The mediating effects of service interactions with hotel employees. J Travel Tour Mark 36:90-106. https://doi.org/10.1080/10548408. 2018.1494087

Rajaguru R, Hassanli N (2018) The role of trip purpose and hotel star rating on guests' satisfaction and WOM. Int J Contemp Hosp Manag 30:2268-2286. https://doi.org/10.1108/IJCHM-01-2017-0044

Rather RA, Sharma J (2017) The effects of customer satisfaction and commitment on customer loyalty: Evidence from the hotel industry. J Hosp Appl Res Tour 12:41-60

Reich AZ, McCleary KW, Tepanon Y, Weaver PA (2006) The impact of product and service quality on brand loyalty: An exploratory investigation of quick-service restaurants. J Foodserv Bus Res 8:35-53. https://doi.org/10.1300/J369v08n03_04

Richards G (2021) Evolving research perspectives on food and gastronomic experiences in tourism. Int J Contemp Hosp Manag in Press. https://doi.org/10.1108/JCHM-10-2020-1217

Ruiz D, Castro B, Diaz I (2012) Creating customer value through service experiences: an empirical study in the hotel industry. Tour. Hosp. Manag 18:37-53

Ryu K, Han H, Kim TH (2008) The relationships among overall quick-casual restaurant image, perceived value, customer satisfaction, and behavioral intentions. Int J Hosp Manag 27:459-469. https://doi. org/10.1016/j.ijhm.2007.11.001

Samuels P (2017) Advice on exploratory factor analysis. http://www.open-access.bcu.ac.uk/6076/1/ staff_shares_storage\%20500mb_Library_ID112668_Stats\%20Advisory_New\%20Statistics\% 20Workshops_18ExploratoryFactorAnalysis_ExploratoryFactorAnalysis4.pdf

San Martín Gutiérrez H, Herrero Crespo A, García de los Salmones MDM (2019) An integrative model of destination brand equity and tourist satisfaction. Curr Issues Tour 22:1992-2013. https://doi.org/ $10.1080 / 13683500.2018 .1428286$

Sangwan AD, Bhakar SS (2018) The effect of service quality, brand image and customer satisfaction on customer loyalty: evidence from hotel industry. Pres Int J Manag IT-Sanchayan 7:1-15

Santos J (2002) From intangibility to tangibility on service quality perceptions: a comparison study between consumers and service providers in four service industries. Manag Serv Qual 12:292-302. https://doi.org/10.1108/09604520210442083

Shah SNU, Jan S, Baloch QB (2018) Role of service quality and customer satisfaction in firm's performance: Evidence from Pakistan hotel industry. Pakistan J Commer Soc Sci 12:167-182

Shahin A, Debastani R (2010) Correlation analysis of service quality gaps in a four-star hotel in Iran. Int Bus Res 3:40-46

Shahin A, Dehghan A, Albadvi A (2006) Service quality gaps and six sigma with a case study on CCG (customer centric group). Proc Sec Intl Conf Six Sigma Glasgow:50-64

Shams G, Rather R, Abdur Rehman M, Lodhi RN (2020) Hospitality-based service recovery, outcome favourability, satisfaction with service recovery and consequent customer loyalty: an empirical analysis. Int J Cult Tour Hosp Res in Press. https://doi.org/10.1108/IJCTHR-04-2020-0079

Shamsudin MF, Esa SA, Ali AM (2019) Determinants of customer loyalty towards the hotel industry in Malaysia. Intl J Inno Creat Chang 6:21-29

Singh A, Jaykumar P (2019) On the road to consensus: key soft skills required for youth employment in the service sector. Worldw Hosp Tour Themes 11:10-24. https://doi.org/10.1108/ WHATT-10-2018-0066

Sisson LG, Adams AR (2013) Essential hospitality management competencies: The importance of soft skills. J Hosp Tour Manag 25:131-145. https://doi.org/10.1080/10963758.2013.826975

So KKF, Oh H, Min S (2018) Motivations and constraints of Airbnb consumers: Findings from a mixedmethods approach. Tour Manag 67:224-236. https://doi.org/10.1016/j.tourman.2018.01.009

Sönmez S, Apostolopoulos Y, Lemke MK, Hsieh YCJ (2020) Understanding the effects of COVID-19 on the health and safety of immigrant hospitality workers in the United States. Tour Manag Perspect 35:100717. https://doi.org/10.1016/j.tmp.2020.100717

Statista (2020) Percentage change in revenue per available room (RevPar) of hotels in selected European countries from February to March 2020. https://www.statista.com/statistics/1105462/impact-ofcovid-19-on-hotel-revpars-in-europe/

Steenkamp JBE, Geyskens I (2012) Transaction cost economics and the roles of national culture: a test of hypotheses based on Inglehart and Hofstede. J Acad Mark Sci 40:252-270. https://doi.org/10.1007/ s11747-011-0266-1 
Stefano NM, Casarotto FN, Barichello R, Sohn AP (2015) A fuzzy SERVQUAL based method for evaluated of service quality in the hotel industry. Proc CIRP 30:433-438. https://doi.org/10.1016/j.procir.2015.02.140

Stringam B, Gerdes J (2019) Service gap in hotel website load performance. Int J Hosp Rev 33:16-29. https://doi.org/10.1108/IHR-09-2018-0012

Su X, Spierings B, Dijst M, Tong Z (2020) Analysing trends in the spatio-temporal behaviour patterns of mainland Chinese tourists and residents in Hong Kong based on Weibo data. Curr Issues Tour 23:1542-1558. https://doi.org/10.1080/13683500.2019.1645096

Sunil MP, Shobharani H, Mathew AK, Rose AE (2018) Validation of SERVQUAL model in star hotels pertaining to Bengaluru City. Asian J Manag 9:393-399. https://doi.org/10.5958/2321-5763.2018. 00060.4

Sureshchander GS, Rajendran C, Anatharaman RN (2002) The relationship between service quality and customer satisfaction: A factor specific approach. J Serv Mark 16:363-379. https://doi.org/10. $1108 / 08876040210433248$

Sweeney JC, Soutar GN (2001) Consumer perceived value: The development of a multiple item scale. J Retail 77:203-220. https://doi.org/10.1016/S0022-4359(01)00041-0

Tiedemann N, van Birgele M, Semeijn J (2009) Increasing hotel responsiveness to customers through information sharing. Tour Rev 64:12-26. https://doi.org/10.1108/16605370911004548

Um S, Chon K, Ro Y (2006) Antecedents of revisit intention. Ann Tour Res 33:1141-1158. https://doi. org/10.1016/j.annals.2006.06.003

Umasuthan H, Park OJ, Ryu JH (2017) Influence of empathy on hotel guests' emotional service experience. J Serv Mark 31:618-635. https://doi.org/10.1108/JSM-06-2016-0220

Veloso BM, Leal F, Malheiro B, Burguillo JC (2020) A 2020 perspective on online guest profiling and hotel recommendation: reliability, scalability, traceability and transparency. Electron Commer Res Appl 40:100957. https://doi.org/10.1016/j.elerap.2020.100957

Wahid SNS, Dangi MRM, Jabar F, Muhamed MFAA, Paino H (2017) Effect of tangibility and reliability service quality towards homestay customer satisfaction. J Tour Hosp Env Manag 2:44-53

Wang TL, Tran PTK, Tran VT (2017) Destination perceived quality, tourist satisfaction and word-ofmouth. Tour Rev 72:392-410. https://doi.org/10.1108/TR-06-2017-0103

Weber MR, Lee J, Crawford A (2020) A suggested best practices for enhancing performance of soft skills with entry-level hospitality managers. Anatolia 31:76-87. https://doi.org/10.1080/13032917.2019. 1703770

Wei SP, Shih SC, Lin SC, Liu CJ, Lu YW, Chang WL (2011) Primary caregivers satisfaction and its related factors in home health care services. Int J Gerontol 5:107-111. https://doi.org/10.1016/j. ijge.2011.05.001

Westbrook RA, Oliver RL (1991) The dimensionality of consumption emotion patterns and consumer satisfaction. J Consum Res 18:84-91. https://doi.org/10.1086/209243

Wongkitrungrueng A, Nuttavuthisit K, Szabo-Douat T, Sen S (2019) Customer deference to service providers in ordinary service encounters. J Serv Theory Pract 29:189-212. https://doi.org/10.1108/ JSTP-02-2018-0031

Woo M (2019) Assessing customer citizenship behaviors in the airline industry: investigation of service quality and value. J Air Transp Manag 7640-7647. https://doi.org/10.1016/j.jairtraman.2019.02. 006

Woodall T (2001) Six sigma and service quality: Christian Gronroos revisited. J Mark Manage 7:595607. https://doi.org/10.1362/026725701323366953

Wu HC, Chang YY (2019) What drives advocacy intentions? A case study of Mainland Chinese tourists to Taiwan. J China Tour Res 15:213-239. https://doi.org/10.1080/19388160.2018.1556140

Wu CHJ, Liang RD (2009) Effect of experiential value on customer satisfaction with service encounters in luxury-hotel restaurants. Int J Hosp Manag 28:586-593. https://doi.org/10.1016/j.ijhm.2009.03. 008

Xiang Z, Du Q, Ma Y, Fan W (2018) Assessing reliability of social media data: lessons from mining TripAdvisor hotel reviews. Inf Technol Tour 18:43-59. https://doi.org/10.1007/s40558-017-0098-Z

$\mathrm{Xu}$ X (2020) Examining an asymmetric effect between online customer reviews emphasis and overall satisfaction determinants. J Bus Res 106:196-210. https://doi.org/10.1016/j.jbusres.2018.07.022

Yang FX, Lau VMC (2015) Luxury hotel loyalty - a comparison of Chinese Gen X and Y tourists to Macau. Int J Contemp Hosp Manag 27:1685-1706. https://doi.org/10.1108/IJCHM-06-2014-0275

Yarimoglu E, Gunay T (2020) The extended theory of planned behavior in Turkish customers' intentions to visit green hotels. Bus Strategy Environ 29:1097-1108. https://doi.org/10.1002/bse.2419 
Ying S, Chan JH, Qi X (2020) Why are Chinese and North American guests satisfied or dissatisfied with hotels? An application of big data analysis. Int J Contemp Hosp Manag 32:3249-3269. https://doi. org/10.1108/IJCHM-02-2020-0129

Yun T (2021) 'Better than we expected': one traveller recounts positive experience at a quarantine hotel. March 3 CTVNews.ca. Retrieved from https://www.ctvnews.ca/canada/better-than-we-expectedone-traveller-recounts-positive-experience-at-a-quarantine-hotel-1.5332217

Žabkar V, Arslanagić-Kalajdžić M (2014) The impact of corporate reputation and information sharing on value creation for organizational customers. South East Eur J Econ Bus 8:42-52. https://doi.org/10. 2478/jeb-2013-0009

Zeithaml VA, Bitner MJ, Gremier DD (2006) Service Marketing: Integrating Customer Focus Across The Firm, 3rd edn. McGraw-Hill, New York, NY

Zhang J, Beatty SE, Walsh G (2008) Review and future directions of cross-cultural consumer services research. J Bus Res 61:211-224. https://doi.org/10.1016/j.jbusres.2007.06.003

Publisher's Note Springer Nature remains neutral with regard to jurisdictional claims in published maps and institutional affiliations. 